\title{
The Geography of Investment: Informed Trading AND Asset PRICES*
}

\author{
Joshua D. Coval \\ University of Michigan Business School \\ and \\ Tobias J. Moskowitz \\ The University of Chicago
}

August 1999

\begin{abstract}
This paper uses geography to shed light on the role of asymmetric information in asset pricing. Demonstrating that investors possess significant informational advantages in evaluating nearby investments, we find that active mutual fund managers overweight proximate firms in their portfolios and earn substantial abnormal returns in local holdings. These findings are more pronounced among funds which are small, have few holdings, and operate out of remote locations. Aggregating across all funds, we use the fraction of a stock's shares held by local investors as a measure of the information asymmetry in its investor base. We find that a firm's degree of local ownership is positively related to the cross-section of expected returns, even when controlling for other factors known to explain return variation. The results document new evidence of informed trading and establish a link between such trading and asset prices.
\end{abstract}

${ }^{*}$ We thank Michael Brennan, Ty Callahan, Gordon Delianedis, Mark Garmaise, Mark Grinblatt, Gur Huberman, Andrew Lo, Lubos Pastor, and seminar participants at the Univesity of Michigan and MIT (Sloan) for helpful comments and discussions. Moskowitz thanks the Center for Research in Security Prices and the Dimensional Fund Advisors Research Fund for financial support. Special thanks to Kent Daniel, Mark Grinblatt, Sheridan Titman, and Russ Wermers for graciously supplying adjusted return data and to Laura Field for providing data on initial public offerings.

Correspondence to: Tobias J. Moskowitz, Graduate School of Business, University of Chicago, 1101 E. 58th St., Chicago, IL 60637. Phone: (773) 834-2757. e-mail: tobias.moskowitz@gsb.uchicago.edu. 


\title{
The Geography of Investment: INFORMED TRADing AND Asset PRICES
}

\begin{abstract}
This paper uses geography to shed light on the role of asymmetric information in asset pricing. Demonstrating that investors possess significant informational advantages in evaluating nearby investments, we find that active mutual fund managers overweight proximate firms in their portfolios and earn substantial abnormal returns in local holdings. These findings are more pronounced among funds which are small, have few holdings, and operate out of remote locations. Aggregating across all funds, we use the fraction of a stock's shares held by local investors as a measure of the information asymmetry in its investor base. We find that a firm's degree of local ownership is positively related to the cross-section of expected returns, even when controlling for other factors known to explain return variation. The results document new evidence of informed trading and establish a link between such trading and asset prices.
\end{abstract}


A key assumption behind the classic Capital Asset Pricing theory of Sharpe (1964), Lintner (1965), and Black (1972) is that investors are perfectly informed about security returns. The past two decades have witnessed a proliferation of research exploring the consequences of relaxing this assumption. Early work focused on the strategic effects of asymmetric information on investor behavior and the price formation process. ${ }^{1}$ More recently, the role of asymmetric information in determining equilibrium expected returns has been addressed (e.g., Merton (1987), Wang (1993, 1994), and Jones and Slezak (1999)). These models show that under rational expectations, securities whose information is available to a limited set of investors offer greater expected returns than those with widely dispersed information. Because investors avoid securities in which they face informational disadvantages due to adverse selection risk, a premium is required for such firms in equilibrium. Consequently, informed investors assume above-average ownership shares in such securities, and in doing so, earn above-average expected returns.

The description of equilibrium asset pricing under asymmetric information has proven difficult to assess empirically, however. Theory offers little guidance in distinguishing between securities with scarce information from those with widely-available information. In addition, theory offers no way to identify informed investors in the investor population. Proxies for information asymmetry, such as measures of consensus among analyst earnings forecasts or bid-ask spreads have had little success describing asset returns. ${ }^{2}$ Furthermore, the existence of a set of informed investors who consistently outperform the market has proven difficult to document. Professional money managers, for instance, do not appear well informed. Most studies find even their pre-expense risk-adjusted performance to be significantly below that of the market or other passive benchmarks. ${ }^{3}$ Similarly, insiders, while perhaps possessing a significant informational advantage relative to the market, appear limited, both legally and otherwise, in their ability to consistently exploit this advantage. Under certain circumstances insiders have been shown to exhibit a degree of timing ability, ${ }^{4}$ but there is little

\footnotetext{
${ }^{1}$ See for example Grossman (1976), Grossman and Stiglitz (1980), Hellwig (1980), Kyle (1985), and Admati (1985).

${ }^{2}$ Merton (1987) and Jones and Slezak(1999) argue that characteristics which explain cross-sectional variation in expected returns, such as size and book-to-market equity, may proxy for how asymmetrically-informed the market is vis-à-vis a particular security. This claim would find considerable support if a set of investors were identified who appeared better-informed than the market, and who earned above-average returns in their selections of small, high book-to-market stocks.

${ }^{3}$ Chevalier and Ellison (1999) find that the mutual funds in their sample underperform the market by 41 basis points per year over the period 1988 to 1993. Carhart (1997) also reports an average annual risk-adjusted return of $-0.5 \%$ for his sample of funds from 1961 to 1993. Daniel, Grinblatt, Titman, and Wermers (1997) report a small $0.5 \%$ return per year on their sample of funds from 1975 to 1994.

${ }^{4}$ Seyhun (1999) presents a variety of evidence which relates changes in insider ownership to changes in returns, but does not document consistent performance among insiders.
} 
evidence that insiders tend to own greater fractions of stocks which outperform the market.

In this paper, we offer a unique method for distinguishing informed from uninformed investors and for identifying securities about which the market is asymmetrically informed from those about which it is uniformly informed. We appeal to a notion widely accepted among practitioners, yet largely ignored by academic financial economists: Investors have better information about nearby firms than distant ones. ${ }^{5}$ If geographic proximity and information are related, then this presents a considerable opportunity for investigating the role of information in asset pricing. Using the distance between an investor and an investment as a measure of information flow, investors can be identified as "informed" with respect to a given stock when they are geographically closer to the firm than the average investor. Similarly, securities held largely by asymmetrically-informed investors can be identified as those whose owners tend to be closer in proximity than the average investor.

Using geographic proximity as an instrument for the quality of investor information, we examine a variety of implications of asymmetric information. Our study focuses on the domestic equity positions of a set of U.S. mutual fund managers over a 20-year period. We begin by verifying that geographic proximity measures the quality of investor information by testing whether fund local holdings outperform non-local holdings. We find that our sample of mutual fund managers exhibit a strong preference for geographically local equities, and generate significant abnormal returns from their local trades. Over the 20-year period, the average manager held stocks which were, on average, $14 \%$ closer to her than the universe of available investments, and earned her an additional $2.5 \%$ annual return relative to the rest of her portfolio. Adjusting returns for size, book-to-market equity, and momentum reduces the spread between local and non-local investments to $1.3 \%$ per annum, but maintains substantial statistical significance. Moreover, the $1.3 \%$ adjusted return is more than twice the magnitude of the overall mutual fund underperformance documented in the literature. The high excess returns of local versus distant holdings is strong in all but the aggressive growth funds, the U.S. holdings of international funds, and large-city funds. Moreover, in support of the link between proximity and information, we find these results to be most pronounced among funds based in remote locations, funds with low asset values and concentrated holdings, and funds which focus on small, growth stocks. Conversely, local stocks that are ignored by local fund managers perform poorly, slightly underperforming passive benchmarks by 80 basis points per year and lagging their

\footnotetext{
${ }^{5}$ In "Finding Returns by Investing Close to Home," Sandra Block writes that a number of fund managers of state and regional funds believe they can obtain abnormal performance by investing in "their own back yard," with the belief that "geography gives them a competitive advantage." She quotes Conrad Herrmann, manager of Franklin California Growth Fund, as stating, "We have a unique advantage over someone investing from over 3,000 miles away. We read the local newspapers, socialize with people that work for these companies, and we can get a sense for how the region's doing." (USA Today, February 28, 1997).
} 
locally held counterparts by $2.7 \%$ per year, after adjusting for size, book-to-market, and momentum. These results indicate that local fund managers have an informational advantage in local stocks.

Next, we shift the focus of the analysis from the fund manager to the stock perspective. We test whether stocks held by asymmetrically-informed investors (proxied by geographically proximate mutual fund managers) outperform the market. Theory predicts that stocks with high degrees of informed ownership will have higher expected returns. We find that local ownership in a firm is positively related to average returns, even in the presence of factors known to capture a sizeable portion of the cross-sectional variation in average returns. The strong explanatory power of local ownership is impressive - a firm with a $10 \%$ higher local ownership rank ordering has a $3.6 \%$ higher average return, after controlling for size, book-to-market equity (BE/ME), momentum, and industry effects.

Finally, we analyze the relation between fund trading activity and geographic investment. This analysis provides an additional test on the usefulness of geography to identify informed trading, and offers insights into the behavior of informed investors. We find that mutual fund managers buy and sell the same securities as other mutual funds ("follow the herd") in their distant holdings, but "break away from the herd" in their local investments. Again, this is consistent with managers having superior local information, and aids in identifying and understanding informed investor activity.

\section{The Economic Role of Geography}

The success of this study rests on the quality of geographic proximity as a measure for how informed an investor is about a potential investment. We argue that geographic proximity is inversely related to the cost of information acquisition. Investors located near a firm can visit the firm's operations, talk to suppliers and employees, as well as assess the local market conditions in which the firm operates. In addition to lowering the travel, time, and research costs associated with obtaining such information, local investors may also have access to private information. For instance, mutual fund managers and local corporate executives may run in the same circles, belong to the same country club, etc. This potential access to private information is likely to be strongest in smaller, remote cities. We find evidence consistent with this.

Aside from our own results, there is a host of evidence documenting the economic role of geography. Lerner (1995), for instance, finds distance to be an important determinant of the board membership of venture capitalists. He concludes from this that the oversight/monitoring of lo- 
cal firms is less costly than that of distant firms. Audretsch and Feldman (1996) and Audretsch and Stephan (1996) find geography to be an important determinant of innovation and production. Likewise, Jaffe, Trajtenberg, and Henderson (1993), Lucas (1993), and Krugman (1991) all find an important economic role for geography.

In related work to this study, both Coval and Moskowitz (1999a) and Huberman (1999) find strong preferences for geographically local equities among investors. Coval and Moskowitz (1999a) examine a set of institutional money managers, while Huberman (1999) documents a local equity preference at the household level. Both studies relate their findings to the international home bias puzzle - the fact that investors severely overweight their portfolios toward domestic assets. ${ }^{6}$ Coval and Moskowitz (1999a) argue that the local bias among professional money managers is likely due to information asymmetries, while Huberman (1999) argues that the preference for local investment among households is due to a cognitive bias for the familiar. By examining the performance and trading activity of local versus non-local investors, we shed light on the various explanations offered for this phenomenon. Our evidence that local investors outperform their distant counterparts substantiates the link between proximity and information.

The remainder of the paper is organized as follows. Section 1 describes the data and methodology employed in the paper. Section 2 documents the preference for local stocks among our sample of mutual funds and across fund types. Section 3 examines the performance of local and nonlocal investments across mutual fund managers. Section 4 employs geographic proximity as an instrument for investor informativeness. Aggregating across all funds, we conduct the analysis from a stock perspective, assessing the relation between the cross-section of expected returns and degree of local/informed investment in a stock. Section 5 further analyzes the behavior of informed investors by examining fund trading activity in relation to geographic investment. Section 6 concludes the paper.

\section{Data and Methodology}

Our sample consists of merging the Investment Company Common Stock Holdings and Transactions tapes from CDA Investment Technologies, Inc. with latitude and longitude data obtained from Geographic Names Information System Digital Gazetteer (GNISDG), published by the U.S. Geological Survey. The CDA tapes list the quarterly equity holdings of virtually all U.S. mutual funds from

\footnotetext{
${ }^{6}$ French and Poterba (1991) document that U.S. investors hold nearly $94 \%$ of their wealth in domestic securities, virtually ignoring international markets.
} 
December 31, 1974 to December 31, 1994. Since CDA does not require any minimum survival period for its included funds, this database does not suffer from survivorship bias. Further details on the construction of this database and summary statistics can be found in Wermers (1999). We examine only those funds with at least five equity holdings and then match each fund with its management company from Nelson's Directory of Investment Managers, obtaining the corresponding location of the fund manager (city and state). We also exclude index funds from our analysis (identified by Nelson's Directory), focusing on active managers who presumably make informed decisions. This reduces our sample of funds from 393 to 150 in 1975 and from approximately 2,400 to 1,258 in 1994. Using the GNISDG database, which contains the latitude and longitude of every U.S. city, we translate the location of every fund manager into latitude and longitude coordinates.

We then match the quarterly domestic equity holdings of mutual funds from CDA with monthly equity returns from the Center for Research in Securities Prices (CRSP) at the time they are held. In addition, we obtain the location of each stock's firm headquarters ${ }^{7}$ from Disclosure and translate it into latitude and longitude coordinates via the GNISDG.

Table 1 presents descriptive statistics of our sample from these four merged datasets. From January, 1975 to December, 1994 our sample of mutual funds hold between 330 and 4,617 different companies. The average number of funds per year is about 288 , each holding an average $\$ 258.48$ million in assets and equities from roughly 40 different firms. On average at least one of these holdings is in a newly issued firm (IPO - defined as any firm issuing equity shares for the first time within the past five years), and the average market capitalization of the stocks being held is approximately $\$ 300$ million. The average turnover of these stocks (defined as number of shares bought or sold divided by number of shares held in the previous quarter for each stock, averaged over all stocks held by all funds) is about $72 \%$. Finally, the average age of our funds is 17.5 quarters, or almost 4.5 years.

We also report summary statistics for two subsamples: January, 1975 to December, 1984 and January, 1985 to December, 1994. Not surprisingly, the number of funds, total asset value, average number of holdings, age, and average stock size increase in the second half of the sample. In addition, since many fund managers and investment firms are located in New York city, we report summary statistics for all funds located outside of New York city (defined as any fund located at least 100

\footnotetext{
${ }^{7}$ Headquarters location is used as opposed to state of incorporation, for the simple reason that firms tend to incorporate in a state with favorable tax laws, bankruptcy laws, etc., rather than for operational reasons, and typically do not have the majority of their operations in their state of incorporation. In fact, few firms in our sample were headquartered in the same state they were incorporated.
} 
kilometers from downtown Manhattan). The distribution of fund and firm characteristics are similar to the overall sample.

Finally, we report summary statistics for funds in various investment objective categories and located in various metropolitan areas. CDA reports nine self-declared fund investment objective categories beginning June 30, 1980: Aggressive Growth (AG), Growth (G), Growth and Income (G\&I), Balanced (Bal.), International (Int.), Municipal Bond, Bond and Preferred, Metals, and Unclassified funds, most of which are special sector and regional funds. We group funds into one of six investment objective categories by combining municipal bond, bond and preferred, metals, and unclassified funds into our 'Other' fund category, due to their small numbers and small percentage of equity holdings. ${ }^{8}$ The growth-oriented funds (AG, G, and G\&I) comprise the largest fraction of investment, and aggressive growth funds tend to buy smaller firms and more newly issued equities. We also classify funds by their metropolitan location. We place funds into three categories: "large cities" - defined as funds located in any of the 20 largest populated cities at each point in time; "small cities" - defined as funds not located in any of the 20 largest populated cities; and "remote cities" - defined as funds located at least 250 kilometers away from any of the 20 largest populated cities. The 20 largest populated cities are defined by the U.S. Census Bureau at the beginning of the year.

\subsection{The Local Bias Measure}

To assess whether our sample of mutual funds exhibit a preference for geographically local stocks, we compute two distance measures for each fund. We compute the actual distance, $d_{i j}$, between fund $i$ and the headquarters of each firm $j$ it holds. ${ }^{9}$ The dollar-weighted average distance, $d_{i t}$, fund $i$ is from each dollar it invests at each point in time is,

$$
d_{i t}=\sum_{j=1}^{N_{t}} w_{i j, t} \cdot d_{i j, t},
$$

where $w_{i j, t}$ is the fraction of fund $i$ 's assets invested in stock $j$ at time $t$ and $N_{t}$ is the total number of stocks available for investment at time $t$. Since fund $i$ holds a subset of the $N_{t}$ assets, if stock $j$ is not held by fund $i$, then $w_{i j, t}=0 .{ }^{10}$

\footnotetext{
${ }^{8} \mathrm{CDA}$ also provides the fund objectives for December 31, 1974. We therefore use these classifications for the first five years of the sample.

${ }^{9}$ Since locations are identified by latitude and longitude, we calculate the arclength, $d_{i j}$, between each pair: $d_{i j}=\arccos \left\{\cos \left(\operatorname{lat}_{i}\right) \cos \left(\operatorname{lon}_{i}\right) \cos \left(\operatorname{lat}_{j}\right) \cos \left(\operatorname{lon}_{j}\right)+\cos \left(\operatorname{lat}_{i}\right) \sin \left(\operatorname{lon}_{i}\right) \cos \left(\operatorname{lat}_{j}\right) \sin \left(\operatorname{lon}_{j}\right)\right.$

$\left.+\sin \left(l_{a t}\right) \sin \left(l_{a t}\right)\right\}(2 \pi r) / 360$, where lat and lon are fund and company latitudes and longitudes and $r$ is the radius of the earth $(\approx 6,378$ kilometers). See Coval and Moskowitz (1999a) for further details.

${ }^{10}$ Since only CRSP-listed equities are examined, hypothetical rather than actual portfolio weights are employed, where we recompute the weights on each holding as if the true portfolio consisted of CRSP-listed equities only. This
} 
We then determine the average distance fund $i$ is from the universe of domestic assets in which it could invest, ${ }^{11}$ weighting the distance between fund $i$ and every stock in the economy in three different ways: equal-weighting, value-weighting (by market capitalization), and weighting by the stock's share of aggregate fund investment (e.g., weighting by the total dollar amount all mutual funds devote to stock $j$ ). Specifically, the average distance between fund $i$ and the universe of potential investments (the "market") at time $t$ is defined as:

$$
d_{i, t}^{M}=\sum_{j=1}^{N_{t}} w_{j, t}^{M} \cdot d_{i j, t},
$$

where $w_{j, t}^{M}$ is firm $j$ 's share of either the equal-weighted, value-weighted, or aggregate fund investmentweighted portfolio. The difference between these two distance measures is our measure of fund $i$ 's propensity to invest locally (in kilometers), which we call the "local bias" measure for fund $i$,

$$
L B_{i, t}=d_{i, t}^{M}-d_{i, t}
$$

We average these local bias measures across funds, value-weighting funds by their total asset value. We report the time-series average and t-statistics of these measures in Table $2 .{ }^{12}$ Coval and Moskowitz (1999a) show that under the null hypothesis that deviations from the market index (however defined) are unrelated to distance, the average local bias measure, $L B$, should be insignificantly different from zero.

\section{Local Equity Preference}

Table 2 Panel A presents averages of three measures of local bias separated by time period, fund objective, and metropolitan area. The first column presents the average distance fund managers are from their holdings using equation (1). This is compared in subsequent columns to the average distance fund managers are from the equal-weighted, value-weighted, and fund investment-weighted market portfolios calculated from equation (2). The local bias measures are the difference between the average distance between a fund and its holdings, and the subsequent market distances, averaged across funds and time. For virtually all time periods, fund objectives, and metropolitan areas, all is done to ensure the portfolio weights of each fund sum to one.

${ }^{11}$ Only those firms being held by at least one fund are considered as the universe of assets available for investment, since funds may be restricted from holding or simply ignore certain firms. We also ran tests using all available stocks (regardless of whether they were held by at least one of our funds) as the set of equities available for investment, and found very similar results.

${ }^{12}$ Since a fund with a strong local bias in one period may appear to have a local bias in future periods, even if its holdings move away from local stocks over time, we also average the local bias measures for each fund over time separately, and then average across funds. This eliminates any potential serial correlation in fund local bias measures that could inflate statistical significance. However, finding no quantitative difference in the results, we omit these statistics for brevity. 
three local bias measures are statistically and economically significant. Overall local bias tends to be strongest relative to the equal-weighted market and weakest relative to the fund investment-weighted market. Despite a large fraction of funds and stocks being headquartered in New York city, the local bias measure actually rises when we remove New York-based funds from the sample. In addition, the propensity to invest locally has diminished slightly over time.

In examining local equity preference across subsamples and fund categories, we redefine the "market" of securities for each group. Hence, when computing the local bias measure for aggressive growth managers, for example, we compare the distance between aggressive growth managers and their holdings to the universe of stocks held by at least one aggressive growth fund. In this way, our local bias statistics cannot be biased by aggressive growth managers in aggregate focusing on a particular region (e.g., Silicon Valley) or type of security. As Table 2 shows, the propensity to invest locally is prevalent across all fund objective categories. Aggressive growth managers exhibit the weakest local equity preferences, and funds in the 'other' category exhibit the strongest. Since most funds in the 'other' category are specialty sector and regional funds, the large local bias among these funds may seem tautological. However, if geographic proximity were truly irrelevant, then regional funds could be just as easily run from outside the region as inside. We also divide our sample of funds by metropolitan location. If the propensity to invest locally is generated by fund managers having an informational advantage in nearby stocks, then we suspect this advantage to be greatest in regions where there are few competitors and where investment community ties are likely to be strongest. Table 2 presents evidence consistent with this as funds from "large" cities (where the distribution of funds is dense) do not exhibit a significant local bias. On the other hand, funds from "small" cities exhibit a large local equity preference, and funds from "remote" cities exhibit an even greater preference for local stocks. Note that from a diversification standpoint, one might expect the local preference to be weakest in small, remote cities, since firms in these areas comprise a significantly smaller fraction of the market, and tend to be dominated by particular sectors. Furthermore, clients of mutual funds may hold a diversified set of funds. Hence, it may be optimal for fund managers to concentrate investment locally and allow their clients to diversify across managers. However, Coval and Moskowitz (1999b) find that institutional clients of investment managers tend to be local, and tend not to invest with a broad set of management firms. Thus, the clients of mutual fund managers are also geographically localized, making the need for diversification greater. As Section 3 demonstrates, however, this loss of diversification is tempered by higher returns from investing locally. 


\subsection{Economic Significance}

To gauge the economic significance of investor local equity preference, we define a new measure of local bias. We divide each manager's portfolio into two portions: a local portion and a non-local (distant) portion. The local portion of fund $i$ is defined as all holdings which are $95 \%$ closer to fund manager $i$ than the average firm in the market. Here, we define the market to be the aggregate fund investment-weighted portfolio of stocks, our most conservative benchmark. Thus, if fund $i$ is 2,000 kilometers from the aggregate-weighted market (AW market), we define fund $i$ 's local holdings as those within 100 kilometers of the fund's location. The $95 \%$ threshold allows for variation in local definitions across funds. ${ }^{13}$ Panel B of Table 2 compares the average fraction of fund manager $i$ 's holdings which are $95 \%$ closer than the market to the average fraction of the market that exists within this threshold. Value-weighting across all funds (by total asset value), the average fund manager invests $7.12 \%$ of her assets locally, even though only $6.40 \%$ of the market of securities is located within her local area. To put this another way, fund managers consistently overweight their portfolios toward local stocks, deviating by about $1 \%$ from market-implied weights. These deviations are statistically and economically significant across sub-periods, fund objectives, and metropolitan areas. Furthermore, they confirm our inferences using the previous local bias measure that this effect is strongest among funds from small and remote cities. This new local bias measure translates our previous distance measures into an economic variable. Given that the average fund in our sample holds approximately 40 equities, a $1 \%$ portfolio weight tilt toward local stocks seems economically important. This is particularly true for funds from remote cities, who exhibit a $1.28 \%$ portfolio weight tilt and hold predominantly smaller firms. Moreover, in the next subsection we demonstrate that the tilt toward local stocks is stronger among small, growth firms, making the $1 \%$ portfolio weight difference economically more meaningful as well. In Section 3 we further address the economic significance of this investment phenomenon.

\section{$2.2 \quad$ Fund and Stock Attributes}

We further analyze the degree of local bias across a variety of fund and stock attributes. Mutual funds are sorted into quintiles according to total asset value, number of holdings, age, number of IPOs held, turnover, and fund local bias (as measured by equation (3) using the aggregate-weighted market

\footnotetext{
${ }^{13}$ The time-series average of the cross-sectional mean of the $95 \%$ threshold is 98.2 kilometers with a standard deviation of 18.9 kilometers and a minimum and maximum value of 63.5 and 139 kilometers, respectively. We obtain nearly identical results when employing an arbitrary 100 kilometer cutoff to separate local holdings from the rest of a fund's portfolio.
} 
benchmark). Table 3 reports the average distance and 95\% threshold-based local bias measures for the lowest and highest quintiles of each attribute sort. We only report the local bias measures using the aggregate weighted market (AW market) as our benchmark to be conservative.

Local bias appears prevalent across both large and small mutual funds. On the other hand, local bias is clearly more pronounced in mutual funds with fewer holdings, and among older funds. The results are consistent with geographic proximity being an instrument for investor informativeness. Older funds, with more established investment community ties, are more likely to gain a local information advantage. Likewise, funds with more concentrated holdings likely pursue more active strategies and can more easily obtain and monitor information from a smaller number of firms. In addition, local bias appears equally in funds invested in few versus many IPOs and in funds with high and low turnover. Finally, when we sort by the average distance bias measure, we see that substantial dispersion and skewness exists in this measure. The lowest bias quintile exhibits an average bias which is negative but lower in absolute value than the overall bias in the dataset. The quintile of funds with the highest level of bias, on the other hand, hold a portfolio which is 641 kilometers - roughly one-third - closer to them than the market portfolio. These funds also place $18.5 \%$ more of their assets in nearby firms than the dollar fraction of local firms in the market. A comparison of the bias in the two quintiles provides strong additional evidence that the relation between geography and portfolio selection is not random. Firms in the highest bias quintile exhibit a local equity preference 10 times greater than the lowest bias quintile. Furthermore, both the distance and fraction invested measures of local bias appear to be highly correlated. This further highlights the important role geography is playing in the portfolio decisions of fund managers.

To further analyze what drives the preference for local equities, we run cross-sectional regressions of the degree of local bias on a constant and a host of fund and stock attributes. The regressions are run every quarter from January, 1975 to December, 1994 and the time-series averages and t-statistics of the coefficients are computed in the style of Fama and MacBeth (1973). The dependent variable is the percent local bias of each fund holding. For fund $i$ holding firm $j$ at time $t$, this measure is

$$
\frac{d_{i, t}^{M}-d_{i j, t}}{d_{i, t}^{M}},
$$

where $d_{i, t}^{M}$ is the average distance (weighted by aggregate fund investment in each stock) fund $i$ is from all stocks at time $t$, and $d_{i j, t}$ is the distance fund $i$ is from stock $j$ (which it holds at time $t$ ). We scale the dependent variable by $d_{i, t}^{M}$ in order to normalize it as well as account for heteroscedasticity across funds. Two sets of independent variables are employed. The first regression uses a set of 
fund attributes as regressors: fund size (log of total asset value), number of fund holdings, fund age (number of quarters in existence), plus two dummy variables indicating whether the fund resides in a small or remote city. The regression specification allows us to gauge the marginal impact of the previously used fund attributes on the propensity to invest locally. For instance, funds from small and remote cities also have relatively few holdings. Hence, it is interesting to examine whether these attributes remain significant controlling for the other, as well as additional fund characteristics. Table 4 confirms our previous results that both the number of holdings and remote city location are highly economically and statistically significant in explaining local investment. However, the explanatory power of small city location appears to be subsumed by the other variables.

The propensity of local investment may be related to stock attributes as well. For instance, Coval and Moskowitz (1999a) find local bias is stronger among small, growth firms. In addition, stock attributes may be confounded with fund attributes. Falkenstein (1996) documents that mutual funds have preferences for large, liquid, and visible firms. However, these firms are more likely to be headquartered in large metropolitan areas, and hence are unlikely driving our results. On the other hand, funds from remote cities may only be interested in small stocks, which predominantly reside in remote locations. We attempt to control for this potential bias in Table 2 by examining the geographic investment choices of each remote city fund relative to all other remote city funds. However, it is interesting to see if certain stock characteristics are related to local investment and help explain this phenomenon. The second regression employs a set of stock attributes as regressors: firm size (log of market capitalization), book-to-market equity (BE/ME), prior month's return (ret_1:-1), cumulative return on the stock from month $t-12$ to $t-2$ (ret-12:-2), cumulative return on the stock from month $t-36$ to $t-13$ (ret-36:-13), cumulative return on the industry portfolio to which each stock belongs from month $t-12$ to $t-1\left(\right.$ ind $\left.d_{-12:-1}\right)$, cumulative return on the regional portfolio to which each stock belongs from month $t-12$ to $t-1$ (reg-12:-1), a dummy variable indicating if the firm was a new issue in the last five years $\left(D_{i p o}\right)$, a dummy variable indicating if the firm trades on the NASDAQ-NMS, and the standard deviation of the firm's monthly return over the past 12 months.

Size and BE/ME are inspired by the results in Coval and Moskowitz (1999a) as well as a series of papers by Fama and French $(1992,1993,1996)$ claiming these variables explain the cross-section of expected stock returns and proxy for systematic risk. The ret $_{-1:-1}$ variable controls for potential microstructure effects, such as bid-ask bounce, found by Jegadeesh (1990) to induce negative autocorrelation in one-month returns. The ret $_{-12:-2}$ and ret $_{-36:-13}$ variables capture the short-term 
return persistence and long-term return reversals documented by Jegadeesh and Titman (1993) and DeBondt and Thaler (1985), respectively. These variables have been shown to be related to future returns, and hence may explain investor portfolio selection. In addition, past returns of individual stocks have been shown by Grinblatt, Titman, and Wermers (1995) to influence mutual fund trades. The industry and regional past returns control for past performance of the various sectors and regions to which each firm belongs. ${ }^{14}$ In addition, Moskowitz and Grinblatt (1999) show that a significant portion of individual stock autocorrelation return patterns are influenced by a prominent industry return autocorrelation pattern. The IPO dummy controls for the influence of new issues, which Ritter (1991) documents abnormally low returns for. The NASDAQ dummy controls for exchange listing. Since the NASDAQ-NMS contains a larger fraction of IPOs and smaller firms, and contains firms from more growth-type industries than the NYSE or AMEX, it is interesting to see if exchange listing is important in the presence of the size, BE/ME (a growth proxy), industry, and IPO variables. Finally, we include the monthly standard deviation of the stock's return over the previous 12 months as a proxy for its idiosyncratic risk.

Table 4 reports the time-series average coefficients from these regressions. Both firm size and $\mathrm{BE} / \mathrm{ME}$ are highly statistically and economically significant. This is consistent with the results in Coval and Moskowitz (1999a) as well as those in Kang and Stulz (1997), who analyze the differences in investment in Japanese firms across foreign and domestic investors. Local bias is unrelated, however, to the past returns of the holding or to those of its industry or region. Controlling for size, BE/ME, and industry, both IPOs and NASDAQ-listed holdings are strongly related to the degree of local investment. A firm issuing new shares within the last five years is $12 \%$ closer, and the average NASDAQ-NMS listed firm is $4.3 \%$ closer, to a fund than the rest of its holdings. Finally, local investment also tends to be stronger in firms with high return variance.

The final regression combines the fund and stock attributes, unaltering the coefficients. The results are consistent with geographic proximity preferences being driven by informational asymmetries between local and non-local investors. Small, growth firms with large return volatility (i.e., risky firms) offer the largest returns from informed trading. Similarly, IPOs because of limited public information and low market visibility, offer local investors a potentially larger information advantage. Finally, the larger bid-ask spreads of NASDAQ-traded stocks may reflect the trades of informed investors. ${ }^{15}$

\footnotetext{
${ }^{14}$ Industry returns are value-weighted portfolio returns of stocks belonging to two digit Standard Industrial Classification Code groupings defined in Moskowitz and Grinblatt (1999). The regional portfolio return for each stock $j$ is the value-weighted average return of stocks within a 500 kilometer radius of firm $j$.

${ }^{15}$ See Christie and Schultz (1994) for evidence of wider bid-ask spreads on NASDAQ and Glosten and Milgrom
} 


\section{Local Investment and Fund Performance}

In this section, we examine the relationship between local bias and information more closely by shifting our focus to investment performance.

\subsection{Local versus Distant Holdings}

We start by examining whether funds generate higher returns from their local investments than their distant ones. We again divide each fund manager's portfolio into a local and distant portion, using the $95 \%$ threshold from the previous section (i.e., local firms are $95 \%$ closer to the manager than the average firm in the market). Holdings within both the local and distant portions of the fund are rescaled to sum to one, thereby creating a "local" and "distant" portfolio for each fund manager. Since CDA contains quarterly holdings positions, we do not know whether these positions reflect beginning or end of quarter holdings (or something in between) for a given fund. Therefore, we update the fund's portfolio holdings at the beginning of every quarter, and hold them constant over the subsequent three months. For example, the fund positions from the third quarter of 1980 (ending September, 1980) are employed with returns from October, November, and December, 1980. This conservative approach ensures against a "look ahead" bias contaminating our results. We compute monthly returns on both the local and distant portions of every fund. For fund manager $i$ at time $t$, this is calculated as,

$$
\tilde{R}_{i, t}^{L}=\frac{1}{3} \sum_{z=1}^{3} \sum_{j=1}^{L_{i, t}} w_{i j, t}^{L} \tilde{r}_{j, t+z} \quad \tilde{R}_{i, t}^{D}=\frac{1}{3} \sum_{z=1}^{3} \sum_{j=1}^{D_{i, t}} w_{i j, t}^{D} \tilde{r}_{j, t+z}
$$

where $\tilde{R}_{i, t}^{L}$ and $\tilde{R}_{i, t}^{D}$ are the average monthly returns over the quarter on fund $i$ 's local and distant holdings, respectively, $L_{i, t}$ and $D_{i, t}$ are the number of local and distant firms held by fund $i$ at time $t, w_{i, t}^{L}$ and $w_{i, t}^{D}$ are the rescaled (to sum to one) portfolio weights applied to fund $i$ 's local and distant holdings, and $\tilde{r}_{j, t}$ is the return on stock $j$ at time $t$ minus the 3 -month Treasury Bill rate. We then average each local and distant return across all funds at time $t$ (weighted by total asset value) and report the time-series average from January, 1975 to December, 1994.

Table 5 reports the average monthly excess returns and Sharpe ratios on the local and distant positions, as well as the difference between them. The returns in Table 5 are annualized, and indicate that over our sample period mutual funds gained an additional $2.5 \%$ per year from their local investments over their non-local ones. However, the Sharpe ratios indicate that the local positions (1985) for a theoretical treatment of the effect of information asymmetries on the spread. 
are riskier. In addition, we learned in the previous section that locally held securities tend to be small cap and growth firms, which have more volatile but high average returns. Consequently, we are interested in the risk-adjusted performance of the local and distant positions in funds. We employ the risk adjustment method of Daniel, Grinblatt, Titman, and Wermers (1997), who subtract from each stock return the return of a well-diversified portfolio of similar size, BE/ME, and momentum (past year return) attributes. ${ }^{16}$ We employ the matched-attribute adjustment method since Daniel and Titman (1997) show that characteristics better describe the cross-section of average returns than covariation with pre-specified factors. ${ }^{17}$

Table 5 shows that even after adjusting for size, BE/ME, and momentum, local holdings still significantly outperform distant holdings by 130 basis points per year. This is perhaps our best evidence that geographic proximity is related to investor informativeness. The performance is primarily driven by the first half of the sample, where local positions earn $2.38 \%$ per year more than distant ones. This is consistent with earlier evidence that local equity preferences are stronger in the first half of our sample. Again, with the advent of the internet and phenomenal growth in information technology, it is not too surprising that a local information advantage would dissapate over time. Furthermore, the growth in the mutual fund industry over time has increased the competition for information, and may have significantly reduced the gains from investing locally.

Strong abnormal performance in local holdings is present across all fund objective groups, except aggressive growth and international. The lack of local excess performance in the domestic holdings of international funds may not be surprising given their focus on investments abroad. Furthermore, the strongest local performance exhibited by funds in our 'other' category is consistent with these funds also exhibiting the largest local bias in Table 2.

To further investigate the relation between geographic proximity and information, we examine the relative performance of local and distant positions across a variety of fund characteristics. Funds

\footnotetext{
${ }^{16}$ These three stock characteristics have been shown to be the best predictors of average stock returns (see Fama and French (1993, 1996), Jegadeesh and Titman (1993), and Daniel and Titman (1997)), and represent feasible investment strategies investors could pursue with no knowledge of firm-specific information. The DGTW procedure first sorts all stocks into size quintiles, then within each size quintile sorts stocks into BE/ME quintiles, and finally within BE/ME quintiles sorts stocks into momentum (past 12-month return) quintiles. The benchmark portfolios are formed by value-weighting the stocks within each of these 125 groups. Stock $j$ is then matched with one of the 125 portfolios based on its size, BE/ME, and past year return from the previous month and the return of the matched portfolio is subtracted from stock $j$ 's return at time $t$. Daniel, Grinblatt, Titman, and Wermers (1997), Daniel and Titman (1997), and Moskowitz and Grinblatt (1999) demonstrate that this characteristic-adjustment method also accounts for the influence of market beta on stock returns. For a detailed description of the methodology and construction of their characteristic-based performance measure, see Daniel, Grinblatt, Titman, and Wermers (1997).

${ }^{17}$ An added benefit of using this method is that Daniel, Grinblatt, Titman, and Wermers (1997) employ their procedure on the same sample of mutual funds from CDA. Our sample differs from theirs in that we exclude index funds and match funds with available fund manager location data from Nelson's Directory of Investment Managers. Our sample contains approximately half as many funds as Daniel, Grinblatt, Titman, and Wermers (1997).
} 
from small, remote metropolitan areas exhibit larger abnormal performance in their local investments than funds from large cities. This is consistent with our information story. Furthermore, since the most talented managers likely reside in large metropolitan areas, this result is not likely driven by a selection bias of better managers. Ex ante, one might expect the worst managers to reside in remote/isolated areas. Fund managers are also sorted into quintiles according to total asset value, number of holdings, age, number of IPOs held, turnover, and fund local bias. Table 5 reports that small funds and funds with fewer holdings exhibit significant abnormal local performance. Large funds and funds with the most holdings do not exhibit a local advantage. The results indicate strongly that information asymmetries drive the local bias phenomenon. Funds following few stocks likely follow them closely, attempting to obtain an informational advantage. This point is further supported by the fact that the number of stocks a fund holds is inversely related to the degree of local investment the fund is pursuing (see Table 3). Likewise, older funds and funds exhibiting higher turnover generate larger abnormal performance from local investment than younger funds with low turnover. Again, this is consistent with these funds likely being better informed locally and trading upon their superior information. To verify that the abnormal performance of local versus distant holdings is not spurious, we also sort funds according to their overall level of local bias. If firms are truly more capable of identifying high-performing local firms than distant ones, firms exploiting this advantage most heavily should display the most significant performance differential. Indeed, Table 5 shows that funds with the highest local bias exhibit large gains from investing locally $(2.07 \%$ per year after adjusting for size, BE/ME, and momentum), while funds with the lowest bias do not exhibit significant local gains.

A fund's participation in the IPO market also appears related to its local performance. Funds holding many IPOs exhibit highly significant local performance, whereas those holding few exhibit no difference between local and distant portfolio returns. Since IPO shares generally tend to be underpriced when issued, ${ }^{18}$ nearby funds may have better access to such shares. Consequently, we report the local minus distant portfolio returns (adjusted via DGTW) excluding all IPOs in column 7 of Table 5. The results are unaltered, indicating that the IPO market is not driving our results. As a final robustness check, we also subtract from each stock return, the return of a portfolio of stocks from the same region. The regional portfolios are value-weighted sums of stocks within a 500 kilometer radius of a given firm. Column 8 of Table 5 reports the local minus distant peformance results for stocks adjusted for size, BE/ME, and momentum; excluding IPOs; and controlling for

\footnotetext{
${ }^{18}$ See Rock (1982) and Barclay and Smith (1987).
} 
the regional return (also adjusted for size, BE/ME, and momentum) of each stock. The results are virtually unchanged. Thus, the abnormal performance of fund local investment cannot be attributed to characteristic-based investment strategies such as small cap, value verus growth, or momentum, investment in IPOs, or performance of the region. The gains from investing locally appear to be due to fund managers having better information about proximately located firms.

\subsection{Local Stocks Not Being Held}

Finally, in addition to examining the performance of stocks in which fund managers invest, it is also interesting to examine the performance of stocks in which they chose not to invest. In particular, what is the subsequent performance of local stocks not chosen by the fund manager? Presumably, local fund managers receive private bad news as well as good news about local companies. However, since mutual funds are largely restricted from taking short positions in firms, both legally and otherwise, analyzing fund holdings may not fully reflect their informational advantage. Hence, bad news about a local firm may only result in local managers ignoring the firm. If geographic proximity reflects information quality, then the performance of local stocks not held by local funds should be significantly worse than local stocks being held, and may even be worse than passive portfolio benchmarks.

Table 5 reports the value-weighted DGTW-adjusted performance of local stocks not being held by local funds. We compute the value-weighted portfolio return of all stocks not held by fund $i$ at time $t$ that are within the $95 \%$ distance threshold of fund $i$, where returns are adjusted for size, BE/ME, and momentum benchmarks via DGTW. The return on this portfolio of local, but not

held, stocks, $\tilde{R}_{i, t}^{L, N H}$, is computed for each fund at time $t$ and averaged across funds weighted by total asset value. Column 9 of Table 5 reports the time-series mean return and annualized Sharpe ratio of these stocks. As the table demonstrates, local stocks ignored by local funds underperform passive benchmarks of size, BE/ME, and momentum, and significantly underperform local stocks being held by an average $2.7 \%$ per year. This evidence further supports our claim that local fund managers have an informational advantage in local stocks. Furthermore, the underperformance of local, ignored stocks indicates that our previous results of local investment outperformance cannot be due to regional effects or characteristics associated with a particular region. For instance, if analysts, the media, and the investment public (other than local investors) are largely unaware of small firms located in remote areas, then the abnormal performance of local investors may simply be due to a neglected firm effect, rather than information asymmetry. However, if this is the case, 
then the performance of local stocks not held by local funds should be similar to those held by the funds. As Table 5 documents, this is not the case, even for funds in remote regions.

The significant abnormal performance exhibited by mutual fund managers in their local holdings is surprising given the paucity of evidence on overall fund performance. Daniel, Grinblatt, Titman, and Wermers (1997) for instance, document a mere 50 basis points per year across all funds in the CDA database. Again, all of this performance occurs in the first half of their sample. Our results indicate that what little ability active managers have appears to come from an advantage in geographically proximate firms. However, as Table 2 documents, only about $7 \%$ of fund assets are invested locally. Since funds are prohibited from holding sizeable positions in firms, this limits the size of their local positions, particularly in small, growth stocks from remote locations. In addition, funds may need to maintain a well-diversified portfolio, limiting the extent of local investment they are willing to make. Hence, we do not see significant mutual fund performance when examining their entire portfolios. One might also wonder why managers do not simply locate in remote areas and reap the gains from a local information advantage. However, the fixed costs of relocating and establishing community ties (which could take years) may prohibit such activity. In addition, fund managers may be more concerned with fund flows and other attributes (see Chevalier and Ellison $(1997,1999))$, that while related to performance, may also be affected by location. For instance, it may be desireable to reside in large metropolitan areas for career concerns, since these markets are more visible and contain large institutional clients.

Finally, our methodology appears to represent a seemingly feasible investment strategy: One that is long all of the local holdings of every fund and short all of their distant holdings. Furthermore, since 'local' is relative to a particular fund manager, the aggregate local minus distant 'strategy' will be geographically diversified. However, such a strategy could only be implemented in practice if mutual fund positions from quarterly SEC filings can be accessed in a timely fashion. Hence, uninformed investors may not be able to mimick the positions of local/informed investors.

\section{Local Investment and the Cross-Section of Expected Stock Returns}

In this section, we shift the focus from the fund manager to the stock. If local investors tend to be better-informed, then a stock's degree of local ownership may reasonably proxy for how asymmetrically-informed its investors are relative to the rest of the market. Using such a measure, 
we can examine whether asymmetric information can explain cross-sectional variation in expected stock returns. In addition, we can analyze the relation between other firm characteristics known to explain average returns (such as size and BE/ME) and our measure.

We begin by identifying stocks held predominantly by local investors, defining the local ownership of stock $j$ as the difference in the distance between stock $j$ 's headquarters and all mutual fund managers, and the distance between its headquarters and those fund managers actually investing in the firm. This difference is then divided by the standard deviation of the distance of stock $j$ from every mutual fund. Specifically,

$$
L O_{j}=\frac{d_{j}^{M}-d_{j}}{\sigma_{j}^{M}},
$$

where $d_{j}^{M}$ is the average distance stock $j$ is from all mutual funds, $\sigma_{j}^{M}$ is the standard deviation of that distance, and $d_{j}$ is the average distance stock $j$ is from the funds that hold it. All distances are value-weighted, with $d_{j}$ calculated using the dollar amount each fund invests in stock $j$ and $d_{j}^{M}$ calculated by weighting distances between firm $j$ and all funds by each fund's total asset value. Thus, if a stock is held by the market of funds, it will have an $L O$ measure of zero, and if it is held predominantly by local funds, then $L O$ will be significantly positive.

\subsection{Fama-MacBeth Regressions}

Using this local ownership variable, we conduct Fama and MacBeth (1973) cross-sectional regressions on the universe of stocks being held by at least one of our mutual funds. Each month, the crosssection of stock returns are regressed on local ownership and a number of variables known to account for cross-sectional variation in expected returns. Specifically, at time $t$ excess stock returns are regressed on a constant, size (the log of market capitalization from the prior month), BE/ME, past one-month firm return $\left(\right.$ ret $\left._{-1:-1}\right)$, cumulative return on the stock from $t-12$ to $t-2\left(\right.$ ret $\left._{-12:-2}\right)$, cumulative return on the stock from $t-36$ to $t-13$ (ret-36:-13), past year's industry return $\left(\right.$ ind $\left.d_{-12:-1}\right)$, past year's regional return $\left(\operatorname{reg}_{-12:-1}\right)$, a remote city dummy variable, indicating if the firm's headquarters resides in a city at least 250 kilometers away from any of the 20 largest populated cities, and the local ownership measure. Coefficients are averaged over time in the style of Fama and MacBeth (1973) and reported in Table 6 along with their time-series t-statistics. The local ownership variable is highly significant in capturing the cross-section of expected returns. However, comparing the regression coefficients on the other characteristics to those run without the $L O$ measure, negligible differences are detected. Hence, the other characteristics continue to account for cross-sectional variation in returns, and do not appear to be affected by the inclusion of 
our variable.

For robustness, we also replace $L O$ with the percentile rank of $L O$. The results are virtually identical. Finally, we also use a pair of dummy variables to capture local ownership: The first one indicates if the stock's $L O$ measure is in the lowest quintile $\left(L D_{\text {low }}\right)$ and the second indicates if the stock's $L O$ measure ranks in the middle three quintiles $\left(L D_{\text {mid }}\right)$. These two dummy variables are employed to help capture a non-linear relation between local ownership and average returns. For instance, beyond a certain distance, investors may be equally uninformed. Hence, firms not in the top quintile of local ownership may have similar average returns. Table 6 indicates that the coefficients on $L D_{\text {low }}$ and $L D_{\text {mid }}$, which are interpreted as deviations from the top quintile, are similar. Hence, beyond the top quintile of $L O$, there is a weak relation between local ownership and expected returns. The results strongly suggest that asymmetric information, as proxied by our local ownership measure, is related to the cross-section of expected stock returns. In particular, firms with highly asymmetrically-informed investors earn a significant return premium.

\subsection{Local Ownership Trading Strategies}

An alternative method for assessing the premium for locally owned firms is to form an investment strategy which buys stocks in the top quintile of local ownership, and shorts those in the bottom quintile. This strategy exploits the informational content of mutual fund managers without acquiring or monitoring that information, and generates a geographically-diversified portfolio. This analysis also provides a robustness check on our previous results and may shed light on the relation between local ownership and expected returns.

Every month we sort stocks into quintiles based on $L O$ from the previous quarter. The valueweighted return of the quintile portfolios are computed every month and time-series averages and t-statistics are reported for the highest and lowest quintiles (LO5 and LO1, respectively), as well as the difference in returns between them $(L O 5-1)$ in Table 7 . Firms in the highest local ownership quintile outperform firms in the lowest $L O$ quintile by 26 basis points per month over our sample period. However, the statistical significance of this spread is marginal. Furthermore, adjusting for factors related to expected returns (notably size, BE/ME, and momentum) the return on LO5 - 1

drops to 20 basis points per month, but is statistically not different from zero. We employ two return adjustment procedures. The first is the DGTW matched portfolio method discussed in Section 3 , and the second is similar to Carhart (1997). The latter method regresses the time-series of LO5 - 1 
portfolio returns on the Carhart (1997) four factor model, consisting of the three Fama and French (1993) factors - excess return on the market (CRSP value-weighted index minus one month Treasury Bill rate), a zero-cost portfolio long small stocks and short large stocks, and a zero-cost portfolio long high BE/ME firms and short low BE/ME firms; plus a momentum benchmark - a portfolio which is long high past year return stocks and short low past year return stocks. The intercept from this regression (e.g., Jensen's $\alpha$ ) represents the abnormal return to our strategy.

Our measure of local ownership is designed to capture the extent to which a firm's stock is held by asymmetrically informed investors. Ideally, we would like to compute a measure that captures the investment made by employees, insiders, and suppliers of the firm, as well as other geographically proximate investors (both individuals and institutions). However, given that we only have mutual fund holding positions, our measure of asymmetric information is likely very noisy. Hence, it is remarkable that our measure is even weakly related to average returns. However, we may be able to reduce the noise of our local ownership measure by examining its relation to expected returns within a subset of firms. For instance, among small firms, local mutual fund managers may comprise a significant fraction of share ownership. On the other hand, among the largest firms, our sample of mutual funds likely comprise a very small fraction of share ownership. Hence, we might expect our local ownership measure to be a better proxy for asymmetric information among smaller firms. In addition, small firms are likely to be more neglected by distant investors and were previously shown to be related to the degree of local investment. Hence, our $L O$ measure should have more explanatory power among the smallest firms.

Table 7 displays the average monthly returns of portfolios sorted first according to firm size (into tretiles) and then sorted by our local ownership measure (into quintiles). Stocks are value weighted within these 15 portfolios, and raw and risk-adjusted returns are reported for the highest and lowest quintiles as well as the difference between them within each size category. The difference in returns between LO5 and LO1 is substantial among the smallest firms, even when we account for size, BE/ME, and momentum premia. However, among the largest firms, no detectable difference between LO5 and LO1 exists. In addition, we first sort stocks by their fraction of equity held by mutual funds - defined for firm $j$ as the number of shares of stock $j$ held by all mutual funds divided by the number of shares outstanding of firm $j$. Again, we expect our $L O$ measure to be more meaningful among firms where mutual funds comprise a greater fraction of ownership. Table 7 confirms our intuition, as the LO5 - 1 spread among firms with the highest mutual fund ownership is almost $5 \%$ per year and between $3.6 \%$ and $6.1 \%$ per year after adjusting for size, BE/ME, and 
momentum. Finally, we also first sort stocks by BE/ME since local investment tends to be stronger among growth stocks. As predicted, the LO5 - 1 spread is strongest among low BE/ME (growth) firms. However, this spread disappears once we adjust returns for risk. On the other hand, growth firms tend to have larger analyst following and greater investor interest. ${ }^{19}$ Hence, it may not be surprising that the relation between $L O$ and expected returns is ambiguous for growth firms.

Overall, the abnormal returns on the $L O 5-1$ strategy are striking given our noisy proxy for asymmetric information and the fact that we adjust for factors known to explain a sizeable portion of the cross-sectional variation in returns. In addition, unlike other variables shown to predict returns (e.g., size, BE/ME, and past returns), our measure is not based on market valuation (i.e., the stock's price). Hence, our results are free from the criticism of Ball (1978) and Berk (1995). ${ }^{20}$

\section{The Behavior of Informed Investors}

Having mounted substantial evidence in support of the hypothesis that local investors are informed investors, we now proceed to examine the behavior of local investors more closely. By examining local investor behavior, we may learn how to better characterize informed investors. We begin by focusing on trading activity. If fund managers receive better information about local equities, then turnover in these investments may differ significantly from non-local investments.

We capture the relationship between local investment and trading activity by regressing the abnormal turnover of a fund in a particular stock on the local bias of that holding as well as a variety of firm and fund characteristics. The regressions are similar to those in Section 2 . Here, the dependent variable is the cross-section of each fund's abnormal turnover in a given stock. For fund $i$ holding stock $j$, abnormal turnover is defined as fund $i$ 's turnover in firm $j$ minus the expected level of turnover in stock $j$. We define turnover as the number of shares bought or sold of firm $j$, divided by the number of shares held in firm $j$ in the previous period. For fund $i$, the abnormal turnover in stock $j$ is,

$$
\tau_{i j, t}^{a b}=\frac{\left|H_{i j, t}-H_{i j, t-1}\right|}{H_{i j, t-1}}-E\left[\frac{\left|H_{i j, t}-H_{i j, t-1}\right|}{H_{i j, t-1}}\right],
$$

where $H_{i j, t}$ is the number of shares fund $i$ holds in stock $j$ at time $t$. The expected value of turnover in firm $j$ is approximated by the average daily trading volume in firm $j$ divided by shares outstanding

\footnotetext{
${ }^{19}$ See Daniel and Titman (1997), Daniel, Hirshleifer, and Subrahmanyam (1999), Hong, Lim, and Stein (1999), and Lee and Swaminathan (1999) for some evidence of this.

${ }^{20}$ Both Ball (1978) and Berk (1995) point out that any misspecification of the asset pricing model will result in variables that include a market-based measure such as price having explanatory power for average returns. Consequently, it is difficult to distinguish whether such variables are economically related to returns or are spuriously related due to model misspecification.
} 
over the prior year. We employ abnormal turnover to control for general trading activity in a stock that is unrelated to geography. The mean abnormal turnover measure across all funds is statistically negligible from zero in every quarter.

As noted in Section 2, local bias is related to a variety of fund and firm characteristics, many of which may also be related to turnover. In order to eliminate confounding factors influencing the frequency of trade in a stock, as well as its relation to geographic proximity, we include these variables in our regression. The independent variables are the same fund and stock attributes used in Section 2 and Table 4, plus the percent local bias of each fund holding defined in equation (4). Again, cross-sectional regressions are conducted each quarter, and the time-series average of the coefficients and their corresponding t-statistics are calculated in the style of Fama and MacBeth (1973) and reported in Table 8.

Controlling for non-geographic factors influencing trade, Table 8 indicates that turnover is highly negatively related to local bias. Managers appear to trade far more frequently in their distant holdings than their local holdings. This result suggests that the kind of information local managers obtain seems to be longer-term, fundamental information which cannot be exploited quickly. On the other hand, manager views on distant holdings appear more volatile. The results are also consistent with international evidence documenting higher turnover for foreign investors than domestic ones (see Tesar and Werner (1995)). Both Brennan and Cao (1997) and Coval (1998) offer asymmetric information models that generate these results. For instance, in the Brennan and Cao (1997) model, distant (foreign) investors trade more due to uncertainty about a local public signal, which only local investors know. Alternatively, the higher turnover in distant firms may be due to a concern for hedging non-tradable goods, having little to do with information asymmetries. ${ }^{21}$ In addition, our results may be consistent with overconfidence among mutual fund managers. As Daniel, Hirshleifer, and Subrahmanyam $(1998,1999)$ and Gervais and Odean (1999) argue, investors are more overconfident about securities which are difficult to assess and value. If distant firms are more difficult for mutual fund managers to monitor and value, then they may be more overconfident in their assessment of these firms, resulting in increased trading activity as Gervais and Odean (1999) suggest.

In addition to examining trading activity from a fund-holding perspective, we also analyze mutual fund trades from a stock perspective. Lakonishok, Shleifer, and Vishny (1992), Grinblatt, Titman, and Wermers (1995), and Wermers (1999) document herding behavior among mutual fund man-

\footnotetext{
${ }^{21}$ For models employing a non-traded goods hedging argument see Stulz (1981), Stockman and Dellas (1989), and Serrat (1998).
} 
agers. We consider whether herding activity differs across stocks according to their degree of local ownership. Similar to Section 4, we run Fama-MacBeth cross-sectional regressions of a measure of herding for each stock on several firm characteristics plus the local ownership measure from equation (6). The herding measure for stock $j$ is similar to that of Lakonishok, Shleifer, and Vishny (1992) and Wermers (1999). We compute the absolute value of the fraction of funds trading in stock $j$ that are buyers less the fraction of trades in all stocks that are buys during time $t$. Specifically, our herding measure for stock $j$ at time $t$ is,

$$
H M_{j, t}=\left|\frac{\# \text { buyer }_{j, t}}{\# \text { trader }_{j, t}}-\frac{\# \text { buy }_{t}}{\# \text { trades }_{t}}\right|,
$$

where \#buyers $s_{j, t}$ reflects the number of funds which increased their holdings of firm $j$ in period t, \#traders $s_{j, t}$ measures the number of funds which changed their holdings of firm $j$ in period $t$, \#buys $s_{t}$ is the total number of purchases made by all mutual funds in period $t$, and \#trades is the total number of trades in period $t$. The explanatory variables in our regression are the firm characteristics from the second row of Table 6: size (log of market capitalization), BE/ME, past month, year, and three year return of the stock, past year return of the stock's industry and region, a remote city indicator variable, and the local ownership measure from equation (6). Time-series average coefficients from the regression are reported in Table 9.

The local ownership measure is highly significant in explaining mutual fund herd behavior. There is a strong inverse relationship between herding activity and geographic proximity. Fund managers appear to herd most strongly in distant firms - breaking away from the herd in their local investments. This is again consistent with local investors having superior information in local firms relative to outsiders.

\section{Conclusion}

The role of asymmetric information in determining equilibrium asset prices, while important in theoretical work, has proven difficult to assess empirically. This paper offers a unique method of identifying firms held by asymmetrically-informed investors. Investors which are located near potential investments, we argue, have significant informational advantages relative to the rest of the market. We find active mutual fund managers exhibit a strong preference for geographically local stocks. This preference appears to be driven by an informational advantage they possess in evaluating local companies. Despite a collection of papers documenting mutual fund underperformance (or lack of performance), we find substantial abnormal performance in the local positions of active managers. 
Moreover, the propensity to invest locally and the performance in local stocks is most pronounced among small funds with concentrated holdings residing in small, remote cities. The trading activity of funds is also consistent with fund managers having superior information about local stocks.

Using geographic proximity as a measure of asymmetric information, we then test the economic influence of asymmetric information on equity prices. We document a positive relation between average returns and the degree of informed investment in a firm. This finding is consistent with equilibrium asset pricing theory under heterogeneously informed investors, which, prior to this study, has eluded empirical verification. Our measure of asymmetric information, although noisy, manages to generate remarkable explanatory power for the cross-section of expected equity returns, independent of factors known to capture stock return variation. Together, these results establish new evidence on informed trading and its influence on equilibrium asset prices.

Our results also provide new insights into the mutual fund industry, offering rare evidence of mutual fund stock selection ability, and shed light on the propensity to invest locally, including, perhaps, the international home bias puzzle. By documenting the relationship between local bias and fund trading activity, we offer insights into the behavior of asymmetrically-informed investors, and identify perhaps the first set of investors which appear better informed than the rest of the market. Finally, our findings contribute to a growing literature on the economic importance of geography. 


\section{References}

Admati, Anat R., 1985, A Noisy Rational Expectations Equilibrium for Multi-Asset Securities Markets, Econometrica, 53, 629-657.

Audretsch, David B. and Maryann P. Feldman, 1996, R\&D spillovers and the geopgraphy of innovation and production, American Economic Review 86, 630-640.

Audretsch, David B. and Paula E. Stephan, 1996, Company-Scientist locational links: The case of biotechnology, American Economic Review 86, 641-652.

Ball, R., 1978, Anomalies in relations between securities' yields and yield-surrogates, Journal of Financial Economics, 6, 103-126.

Banz, Rolf W., 1981, The relationship between return and market value of common stocks, Journal of Financial Economics 6, 103-126.

Berk, Jonathan B., 1995, A critique of size-related anomalies, Review of Financial Studies, 8, 275286 .

Black, Fischer, 1972, Capital market equilibrium with restricted borrowing, Journal of Business, 45, 444-455.

Block, Sandra, February 28, 1997, Finding returns by investing close to home, USA Today, 8B.

Brennan, Michael J., and Cao, H. Henry, 1997, International portfolio investment flows, Journal of Finance 52, 1855-1880.

Carhart, Mark M., 1997, On persistence in mutual fund performance, Journal of Finance, 52, 57-82.

Chevalier, Judith and Glenn Ellison, 1997, Risk-taking by mutual funds as a response to incentives, Journal of Political Economy 105, 1167-1200.

Chevalier, Judith and Glenn Ellison, 1999, Are some mutual fund managers better than others? Cross-sectional patterns in behavior and performance, Journal of Finance, 54, 875-899.

Christie, William G., and Paul Schultz, 1994, Why do NASDAQ market makers avoid odd-eighth quotes?, Journal of Finance, 49, 1813-1840.

Coval, Joshua D., 1998, International capital flows when investors have local information, Working paper, University of Michigan Business School, Ann Arbor, MI.

Coval, Joshua D., and Tobias J. Moskowitz, 1999a, Home bias at home: Local equity preference in domestic portfolios, forthcoming Journal of Finance.

Coval, Joshua D., and Tobias J. Moskowitz, 1999b, On the selection of fund managers by institutional investors, Working paper, University of Michigan.

Daniel, Kent, and Sheridan Titman, 1997, Evidence on the characteristics of cross-sectional variation in common stock returns, Journal of Finance, 52, 1-34.

Daniel, Kent, David Hirshleifer, and Avanidhar Subrahmanyam, 1998, A theory of overconfidence, self-attribution, and security market under- and overreactions, Journal of Finance 53, 1839-1886.

Daniel, Kent, David Hirshleifer, and Avanidhar Subrahmanyam, 1999, Investor Overconfidence, Covariance Risk, and Predictors of Security Returns, Working paper, Northwestern University.

Daniel, Kent, Mark Grinblatt, Sheridan Titman, and Russell Wermers, 1997, Measuring mutual fund performance with characteristic-based benchmarks, Journal of Finance, 52, 1035-1058.

DeBondt, Werner F.M. and Richard Thaler, 1985, Does the stock market overreact?, Journal of Finance, 40, 793-808.

Falkenstein, Eric G., 1996, Preferences for stock characteristics as revealed by mutual fund holdings, Journal of Finance 51, 111-135.

Fama, Eugene F., and James MacBeth, 1973, Risk, return, and equilibrium: Empirical tests, Journal of Political Economy 71, 607-636.

Fama, Eugene F. and Kenneth R. French, 1992, The cross-section of expected stock returns, Journal of Finance 47, 427-465. 
Fama, Eugene F., and Kenneth R. French, 1993, Common risk factors in the returns on stocks and bonds, Journal of Financial Economics, 53, 427-465.

Fama, Eugene F. and Kenneth R. French, 1996, Multifactor explanations of asset pricing anomalies, Journal of Finance 51, 55-84.

French, Kenneth R. and James M. Poterba, 1991, Investor diversification and international equity markets, American Economic Review, 81, 222-226.

Gervais, Simon, and Terrance Odean, 1999, Learning to be Overconfident, Working paper, Wharton School.

Glosten, Larry, and Paul Milgrom, 1985, Bid, ask, and transactions prices in a specialist market with heterogeneously informed traders, Journal of Financial Economics, 13, 71-100.

Grinblatt, Mark, Sheridan Titman, and Russ Wermers, 1995, Momentum investment strategies, portfolio performance, and herding: A study of mutual fund behavior, American Economic Review 85, 1088-1105.

Grossman, Sanford, 1976, On the efficiency of competitive stock markets where traders have diverse information, Journal of Finance, 31, 573-585.

Grossman, Sanford, and Joseph Stiglitz, 1980, On the impossibility of informationally efficient markets, American Economic Review, 70, 393-408.

Hellwig, Martin, 1980, On the aggregation of information in competitive markets, Journal of Economic Theory, 22, 477-498.

Huberman, Gur, 1999, Familiarity breeds investment, Working Paper, Columbia Business School.

Jaffe, Adam B., Manuel Trajtenberg, and Rebecca Henderson, 1993, Geographic localization of knowledge spillovers as evidenced by patent citations, Quarterly Journal of Economics, 63, 577-598.

Jegadeesh, Narasimhan, and Sheridan Titman, 1993, Returns to buying winners and selling losers: Implications for stock market efficiency, Journal of Finance 48, 65-91.

Jones, Charles, and Steve L. Slezak, 1999, The Theoretical implications of asymmetric information on the dynamic and cross-sectional characteristics of asset returns, Working Paper, UNC Chapel Hill.

Kang, Jun-Koo, and René M. Stulz, 1997, Why is there a home bias? An analysis of foreign portfolio equity ownership in Japan, Journal of Financial Economics 46, 3-28.

Keim, Donald B., 1983, Size related anomalies and stock return seasonality: Further evidence, Journal of Financial Economics 12, 13-32.

Krugman, Paul, 1991, Increasing returns and economic geography, Journal of Political Economy 99, 483-499.

Kyle, Albert S., 1985, Continuous auctions and insider trading, Econometrica, 53, 1315-1335.

Lakonishok, Josef, Andrei Shleifer and Robert Vishny, 1992, The impact of institutional trading on stock prices, Journal of Financial Economics, 32, 23-44.

Lerner, Josh, 1995 Venture Capitalists and the oversight of private firms, Journal of Finance 50, 301-318.

Lintner, John, 1965, The valuation of risk assets and the selection of risky investments in stock portfolios and capital budgets, Review of Economics and Statistics, 47, 13-37.

Lucas, Robert E., Jr., 1993, Making a miracle, Econometrica 61, 251-272.

Merton, Robert C., 1987, A simple model of capital market equilibrium with incomplete information, Journal of Finance 42, 483-510.

Moskowitz, Tobias, and Mark Grinblatt, 1999, Do industries explain momentum?, Journal of Finance, 54, 1249-1290.

Ritter, Jay, 1991, The long-run performance of initial public offerings, Journal of Finance, 46, 3-27.

Rosenberg, Barr, Kenneth Reid and Ronald Lanstein, 1985, Persuasive evidence of market inefficiency, Journal of Portfolio Management 11, 9-17. 
Serrat, Angel, 1997, A Dynamic equilibrium model of international risk-sharing puzzles, Working paper, Graduate School of Business, University of Chicago.

Sharpe, William F., 1964, Capital asset prices: a theory of market equilibrium under conditions of risk, Journal of Finance, 19, 425-442.

Stockman, Alan C., and Dellas, Harris, 1989, International portfolio nondiversification and exchange rate variability, Journal of International Economics 26, 271-289.

Stulz, René M., 1981, On the effects of barriers to international investment, Journal of Finance 36, 923-934.

Tesar, Linda L., and Ingrid M. Werner, 1995, Home bias and high turnover, forthcoming Journal of International Money and Finance.

Wang, Jiang, 1993, A model of intertemporal asset prices under asymmetric information, Review of Economic Studies, 60, 249-282.

Wang, Jiang, 1994, A model of competitive stock trading volume, Journal of Political Economy, 102, 127-168.

Wermers, Russ, 1999, Mutual fund herding and the impact on stock prices, Journal of Finance, 34, 581-622. 
Table 1:

Descriptive Statistics for U.S. Mutual Funds

Descriptive statistics on the 1,258 active mutual funds which predominantly hold equities in our sample are reported below over the period January, 1975 to December, 1994. Statistics are computed from reported quarterly mutual fund holdings obtained from CDA, which are then matched with CRSP-listed equities meeting our data requirements.

Reported are the average number of funds, average total value of assets under management, average number of CRSP-listed equities held, average number of firms held which have issued stock for the first time within the last five years (number of IPOs held), average age of the funds in quarters, average percentage turnover of the funds (defined as number of shares bought or sold divided by number of shares held in the previous period), and the average size (market capitalization) of firms held by the funds. Averages across funds are reported over the entire sample period (1975-1994), over the period 1975-1984, and over the period 1985-1994. Also reported are averages for all funds excluding those based in New York city (defined as any fund located beyond 100 kilometers of downtown Manhattan), for funds with self-reported investment objectives of: aggressive growth (AG), growth (G), growth \& income (G\&I), international (Int.), balanced (Bal.), and other (which mainly contains small sector and specialty funds), and for funds located in the 20 largest populated cities ("large city" funds), funds located in any city other than the 20 largest populated cities ("small city" funds), and funds not located within 250 kilometers of any of the 20 largest populated cities ("remote city" funds).

\begin{tabular}{|c|c|c|c|c|c|c|c|}
\hline & $\begin{array}{l}\text { No. of } \\
\text { Funds }\end{array}$ & $\begin{array}{r}\text { Total Asset } \\
\text { Value (\$ mill.) }\end{array}$ & $\begin{array}{c}\text { No. of } \\
\text { Holdings }\end{array}$ & $\begin{array}{l}\text { No. of } \\
\text { IPOs Held }\end{array}$ & $\begin{array}{c}\text { Age } \\
\text { (quarters) }\end{array}$ & Turnover & $\begin{array}{c}\text { Avg. Stock } \\
\text { Size (\$ mill.) }\end{array}$ \\
\hline 1975-1994 & 287.70 & 258.480 & 39.58 & 1.108 & 17.50 & 0.717 & 300.7 \\
\hline 1975-1984 & 142.40 & 127.050 & 21.39 & 0.248 & 13.99 & 0.253 & 169.1 \\
\hline 1985-1994 & 433.00 & 289.927 & 47.77 & 1.967 & 21.00 & 1.182 & 432.2 \\
\hline Excl. NY & 202.70 & 167.928 & 42.10 & 1.199 & 18.42 & 0.871 & 326.2 \\
\hline \multicolumn{8}{|c|}{ Fund Objective } \\
\hline $\mathrm{AG}$ & 32.96 & 255.680 & 33.95 & 2.932 & 20.13 & 0.430 & 224.0 \\
\hline G & 96.08 & 269.326 & 34.35 & 1.306 & 19.69 & 0.453 & 304.2 \\
\hline G\&I & 44.75 & 315.908 & 31.40 & 0.656 & 21.22 & 0.461 & 344.7 \\
\hline Int. & 14.46 & 247.281 & 28.06 & 1.247 & 14.72 & 0.441 & 344.6 \\
\hline Bal. & 21.04 & 253.625 & 30.66 & 0.553 & 21.24 & 0.476 & 384.1 \\
\hline Other & 67.36 & 216.830 & 21.81 & 0.502 & 11.79 & 3.570 & 317.6 \\
\hline \multicolumn{8}{|c|}{ Metropolitan Area } \\
\hline Large & 74.84 & 284.490 & 43.31 & 1.138 & 21.55 & 1.969 & 318.0 \\
\hline Small & 235.90 & 257.767 & 37.26 & 1.173 & 17.57 & 0.410 & 323.3 \\
\hline Remote & 119.00 & 160.414 & 21.15 & 1.301 & 17.39 & 0.447 & 318.8 \\
\hline
\end{tabular}


Table 2:

Local Equity Preference for U.S. Mutual Funds

Panel A reports descriptive statistics on the propensity for our sample of mutual funds to invest in geographically proximate equities. For each of the categories and subperiods reported in Table 1, the average distance between a fund and its holdings, average distance between a fund and all stocks held by at least one mutual fund in each particular category, and the difference between these measures $(L B)$ in kilometers are computed for each fund and then averaged across all funds (value-weighted by total asset value) and reported below, along with t-statistics in parentheses. Three measures of the average distance between a fund and all securities held by all other funds in a particular category are computed by aggregating the actual portfolio weights applied by all funds ("AW Market"), equal-weighting ("EW Market"), and value-weighting ("VW Market") the securities held by all funds in a particular category.

Panel B compares the average fraction of actual fund investment locally (defined as any investment within $95 \%$ of the aggregate weighted market (AW market) distance from the fund) to the fraction of total market capitalization that exists within the fund's local area. The difference between these two measures are reported, along with a t-statistic in parentheses.

\begin{tabular}{|c|c|c|c|c|c|c|c|c|c|c|}
\hline & \multicolumn{7}{|c|}{ Panel A: Average Distances (in km) } & \multicolumn{3}{|c|}{ Panel B: \% Locally } \\
\hline & Holdings & AW Market & $L B$ & EW Market & $L B$ & VW Market & $L B$ & Holdings & Market & Diff. \\
\hline $\begin{array}{l}1975-1994 \\
\text { (t-stat) }\end{array}$ & 1887.54 & 1964.23 & $\begin{array}{r}76.70 \\
(18.98)\end{array}$ & 2202.09 & $\begin{array}{r}314.55 \\
(26.99)\end{array}$ & 1981.03 & $\begin{array}{r}93.49 \\
(24.94)\end{array}$ & 7.12 & 6.40 & $\begin{array}{r}0.72 \\
(9.43)\end{array}$ \\
\hline $\begin{array}{l}1975-1984 \\
\text { (t-stat) }\end{array}$ & 1872.22 & 1956.19 & $\begin{array}{r}83.96 \\
(12.08)\end{array}$ & 2072.97 & $\begin{array}{r}200.75 \\
(32.87)\end{array}$ & 1948.26 & $\begin{array}{r}76.04 \\
(12.50)\end{array}$ & 7.00 & 6.07 & $\begin{array}{r}0.94 \\
(7.73)\end{array}$ \\
\hline $\begin{array}{l}\text { 1985-1994 } \\
\text { (t-stat) }\end{array}$ & 1902.85 & 1972.28 & $\begin{array}{r}69.43 \\
(16.97)\end{array}$ & 2331.21 & $\begin{array}{r}428.36 \\
(25.12)\end{array}$ & 2013.79 & $\begin{array}{r}110.94 \\
(29.13)\end{array}$ & 7.24 & 6.73 & $\begin{array}{r}0.51 \\
(5.61)\end{array}$ \\
\hline $\begin{array}{l}\text { Excl. NY } \\
\text { (t-stat) }\end{array}$ & 1816.65 & 1937.57 & $\begin{array}{r}120.77 \\
(15.55)\end{array}$ & 2133.23 & $\begin{array}{r}316.46 \\
(27.95)\end{array}$ & 1948.98 & $\begin{array}{r}131.86 \\
(17.72)\end{array}$ & 6.97 & 6.01 & $\begin{array}{r}0.96 \\
(7.50)\end{array}$ \\
\hline \multicolumn{11}{|c|}{ Fund Objective } \\
\hline $\begin{array}{l}\mathrm{AG} \\
\text { (t-stat) }\end{array}$ & 1865.45 & 1956.15 & $\begin{array}{r}90.89 \\
(9.04)\end{array}$ & 2162.41 & $\begin{array}{r}296.82 \\
(31.63)\end{array}$ & 1975.15 & $\begin{array}{r}109.73 \\
(11.69)\end{array}$ & 6.94 & 5.95 & $\begin{array}{r}1.00 \\
(5.32)\end{array}$ \\
\hline $\begin{array}{l}\text { G } \\
\text { (t-stat) }\end{array}$ & 1808.17 & 1968.58 & $\begin{array}{l}160.01 \\
(15.63)\end{array}$ & 2119.87 & $\begin{array}{r}310.62 \\
(32.56)\end{array}$ & 1980.15 & $\begin{array}{r}172.44 \\
(17.38)\end{array}$ & 7.11 & 5.89 & $\begin{array}{r}1.22 \\
(7.00)\end{array}$ \\
\hline $\begin{array}{l}\text { G\&I } \\
\text { (t-stat) }\end{array}$ & 1803.16 & 1981.17 & $\begin{array}{r}177.82 \\
(16.76)\end{array}$ & 2088.83 & $\begin{array}{r}284.85 \\
(26.56)\end{array}$ & 1989.14 & $\begin{array}{r}186.07 \\
(17.98)\end{array}$ & 7.20 & 6.57 & $\begin{array}{r}0.63 \\
(3.99)\end{array}$ \\
\hline $\begin{array}{l}\text { Int. } \\
\text { (t-stat) }\end{array}$ & 1779.91 & 2003.31 & $\begin{array}{r}223.74 \\
(18.54)\end{array}$ & 2295.62 & $\begin{array}{r}515.97 \\
(26.10)\end{array}$ & 2034.84 & $\begin{array}{r}254.52 \\
(20.14)\end{array}$ & 7.96 & 6.77 & $\begin{array}{r}1.19 \\
(5.24)\end{array}$ \\
\hline $\begin{array}{l}\text { Bal. } \\
\text { (t-stat) }\end{array}$ & 1779.91 & 2000.01 & $\begin{array}{r}221.64 \\
(22.96)\end{array}$ & 2119.53 & $\begin{array}{r}340.07 \\
(31.71)\end{array}$ & 2016.51 & $\begin{array}{r}236.82 \\
(25.18)\end{array}$ & 7.05 & 5.91 & $\begin{array}{r}1.14 \\
(4.64)\end{array}$ \\
\hline $\begin{array}{l}\text { Other } \\
\text { (t-stat) }\end{array}$ & 1670.81 & 1929.72 & $\begin{array}{r}259.03 \\
(13.71)\end{array}$ & 2239.57 & $\begin{array}{r}568.29 \\
(24.15)\end{array}$ & 1945.32 & $\begin{array}{r}274.34 \\
(13.64)\end{array}$ & 8.48 & 7.16 & $\begin{array}{r}1.32 \\
(3.28)\end{array}$ \\
\hline \multicolumn{11}{|c|}{ Metropolitan Area } \\
\hline $\begin{array}{l}\text { Large } \\
\text { (t-stat) }\end{array}$ & 2073.51 & 2058.72 & $\begin{array}{l}-15.27 \\
(-2.66)\end{array}$ & 2287.45 & $\begin{array}{c}214.14 \\
(20.24)\end{array}$ & 2076.61 & $\begin{array}{r}3.08 \\
(0.49)\end{array}$ & 10.31 & 9.81 & $\begin{array}{r}0.50 \\
(5.23)\end{array}$ \\
\hline $\begin{array}{l}\text { Small } \\
\text { (t-stat) }\end{array}$ & 1852.51 & 1954.46 & $\begin{array}{r}101.41 \\
(19.68)\end{array}$ & 2233.94 & $\begin{array}{r}381.17 \\
(30.65)\end{array}$ & 1977.61 & $\begin{array}{r}125.10 \\
(31.14)\end{array}$ & 7.34 & 6.50 & $\begin{array}{r}0.84 \\
(8.32)\end{array}$ \\
\hline $\begin{array}{l}\text { Remote } \\
\text { (t-stat) }\end{array}$ & 1831.41 & 1983.13 & $\begin{array}{r}152.18 \\
(17.95)\end{array}$ & 2360.09 & $\begin{array}{r}528.91 \\
(43.80)\end{array}$ & 2020.24 & $\begin{array}{r}189.75 \\
(30.78)\end{array}$ & 6.33 & 5.05 & $\begin{array}{r}1.28 \\
(11.27)\end{array}$ \\
\hline
\end{tabular}


Table 3:

Local Equity Preference Across Fund Attributes

Descriptive statistics on the propensity for our sample of mutual funds to invest in geographically proximate equities are reported below. Mutual funds are sorted into quintiles according to total asset value, number of holdings, age, number of IPOs held, turnover, and fund local bias (as measured by equation (3) using the aggregate-weighted market benchmark). The average distance and 95\% threshold-based local bias measures for the lowest and highest quintiles of each attribute sort are reported. For each of the quintiles, the average distance between a fund and its holdings, average distance between a fund and all stocks held by at least one mutual fund in each particular category, and the difference between these measures are reported, along with t-statistics in parentheses. The final three columns report the average fraction of actual fund investment locally (defined as any investment within $95 \%$ of the aggregate weighted market (AW market) distance from the fund), the fraction of total market capitalization that exists within the fund's local area, and the difference between these, along with t-statistics in parentheses.

\begin{tabular}{|c|c|c|c|c|c|c|}
\hline & \multicolumn{3}{|c|}{ Average Distances (in km) } & \multicolumn{3}{|c|}{ \% Locally } \\
\hline & Holdings & AW Market & $L B$ & Holdings & Market & Diff. \\
\hline \multicolumn{7}{|c|}{ Fund Size (total asset value) } \\
\hline Q1 & 1872.54 & 1960.23 & 87.70 & 7.12 & 6.31 & 0.81 \\
\hline low & & & $(11.15)$ & & & $(8.01)$ \\
\hline Q5 & 1907.22 & 1989.19 & 82.96 & 6.85 & 6.41 & 0.44 \\
\hline high & & & $(9.67)$ & & & $(3.19)$ \\
\hline \multicolumn{7}{|c|}{ Number of Fund Holdings } \\
\hline Q1 & 1819.85 & 1984.28 & $\begin{array}{l}165.43 \\
(16.14)\end{array}$ & 7.49 & 6.44 & $\begin{array}{c}1.04 \\
(8.63)\end{array}$ \\
\hline Q5 & 1879.65 & 1941.57 & $\begin{array}{c}61.72 \\
(5.90)\end{array}$ & 6.35 & 6.73 & $\begin{array}{c}-0.38 \\
(-1.39)\end{array}$ \\
\hline \multicolumn{7}{|c|}{ Age of Fund } \\
\hline Q1 & 1859.45 & 1926.15 & $\begin{array}{c}67.89 \\
(7.51)\end{array}$ & 6.69 & 6.89 & $\begin{array}{c}-0.20 \\
(-1.10)\end{array}$ \\
\hline Q5 & 1831.17 & 2005.58 & $\begin{array}{l}173.01 \\
(16.14)\end{array}$ & 7.93 & 6.46 & $\begin{array}{c}1.47 \\
(14.47)\end{array}$ \\
\hline \multicolumn{7}{|c|}{ Number of IPOs Held by Fund } \\
\hline Q1 & 1886.16 & 1965.17 & $\begin{array}{c}79.82 \\
(16.32)\end{array}$ & 7.21 & 6.46 & $\begin{array}{c}0.75 \\
(6.83)\end{array}$ \\
\hline Q5 & 1887.91 & 1983.31 & $\begin{array}{c}96.74 \\
(11.25)\end{array}$ & 7.89 & 6.59 & $\begin{array}{c}1.29 \\
(5.28)\end{array}$ \\
\hline \multicolumn{7}{|c|}{ Fund Turnover } \\
\hline Q1 & 1891.91 & 1947.01 & $\begin{array}{c}55.64 \\
(9.37)\end{array}$ & 6.73 & 6.34 & $\begin{array}{c}0.39 \\
(2.75)\end{array}$ \\
\hline Q5 & 1854.81 & 1945.72 & $\begin{array}{c}90.03 \\
(11.73)\end{array}$ & 6.27 & 5.68 & $\begin{array}{c}0.59 \\
(3.77)\end{array}$ \\
\hline \multicolumn{7}{|c|}{ Fund Local Bias } \\
\hline Q1 & 2012.41 & 1963.72 & $\begin{array}{l}-48.69 \\
(-7.75)\end{array}$ & 2.91 & 4.60 & $\begin{array}{c}-1.69 \\
(-15.71)\end{array}$ \\
\hline Q5 & 1485.51 & 2126.46 & $\begin{array}{l}641.41 \\
(54.33) \\
\end{array}$ & 31.45 & 12.91 & $\begin{array}{c}18.45 \\
(39.38)\end{array}$ \\
\hline
\end{tabular}


Table 4:

Local Equity Preference Across Fund and Stock Attributes

(Fama-MacBeth Cross-Sectional Holdings-Level Regressions)

Cross-sectional regressions are run every quarter over the period January, 1975 to December, 1994 on the universe of mutual fund holdings, where the time-series average of these coefficients are reported below, along with their time-series t-statistics (in parentheses) in the style of Fama and MacBeth (1973).

The dependent variable is the percent (or scaled) local bias of each fund holding. For fund $i$ holding firm $j$ this is the difference between the average distance fund $i$ is from all available securities $\left(d_{i, t}^{M}\right)$ minus the distance fund $i$ is from security $j\left(d_{i j, t}\right)$, divided by $d_{i, t}^{M}$ at time $t$. The cross-section of local bias measures is regressed on a constant (not reported) and a set of mutual fund attributes: $\log$ of fund total asset value, number of fund holdings, age of fund, a small city dummy (indicating if the fund is located outside one of the 20 largest populated cities), and a remote city dummy (indicating if the fund is located outside of 250 kilometers of any of the 20 largest populated cities); plus a set of stock attributes: log of size (market capitalization), book-to-market-equity (BE/ME), past one-month return (ret-1: -1 ), past return from $t-12$ to $t-2$ $($ ret-12:-2), past return from $t-36$ to $t-13$ (ret-36:-13), past industry return to which each stock belongs from $t-12$ to $t-1$ (ind-12:11), past region return to which each stock belongs from $t-12$ to $t-1$ (reg-12:-1), an IPO dummy (indicating whether the firm issued shares for the first time within the last five years), a NASDAQ dummy (indicating whether the firm trades on the NASDAQ-NMS), and the standard deviation of the stock's return over the last year.

\begin{tabular}{|c|c|c|}
\hline $\ln ($ assets $)$ & $\begin{array}{l}0.0000 \\
(-0.33)\end{array}$ & $\begin{array}{r}-0.0001^{* *} \\
(-2.50)\end{array}$ \\
\hline \# holdings & $\begin{array}{r}-0.0008^{* *} \\
(-6.17)\end{array}$ & $\begin{array}{r}-0.0005^{* *} \\
(-4.29)\end{array}$ \\
\hline age & $\begin{array}{r}-0.0005 \\
(-1.66)\end{array}$ & $\begin{array}{r}-0.0004 \\
(-1.30)\end{array}$ \\
\hline small city & $\begin{array}{r}-0.0027 \\
(-0.81)\end{array}$ & $\begin{array}{r}0.0056 \\
(1.60)\end{array}$ \\
\hline remote city & $\begin{array}{r}0.0507^{* *} \\
(20.50)\end{array}$ & $\begin{array}{r}0.0507^{* *} \\
(20.75)\end{array}$ \\
\hline $\ln ($ size $)$ & $\begin{array}{r}-0.0238^{* *} \\
(-18.77)\end{array}$ & $\begin{array}{r}-0.0238^{* *} \\
(-18.88)\end{array}$ \\
\hline $\mathrm{BE} / \mathrm{ME}$ & $\begin{array}{r}-0.0179^{* *} \\
(-7.44)\end{array}$ & $\begin{array}{r}-0.0183^{* *} \\
(-7.54)\end{array}$ \\
\hline ret $_{-1:-1}$ & $\begin{array}{r}-0.0057 \\
(-0.20)\end{array}$ & $\begin{array}{r}-0.0067 \\
(-0.23)\end{array}$ \\
\hline ret $_{-12:-2}$ & $\begin{array}{r}0.0057 \\
(0.75)\end{array}$ & $\begin{array}{r}0.0055 \\
(0.75)\end{array}$ \\
\hline ret $_{-36:-13}$ & $\begin{array}{r}-0.0020 \\
(-0.85)\end{array}$ & $\begin{array}{r}-0.0011 \\
(-0.45)\end{array}$ \\
\hline$i_{n d-12:-1}$ & $\begin{array}{r}-0.0367 \\
(-1.48)\end{array}$ & $\begin{array}{r}-0.0361 \\
(-1.45)\end{array}$ \\
\hline $\operatorname{reg}_{-12:-1}$ & $\begin{array}{r}0.2103 \\
(0.64)\end{array}$ & $\begin{array}{r}0.2096 \\
(0.63)\end{array}$ \\
\hline$D_{i p o}$ & $\begin{array}{r}0.1208^{* *} \\
(9.94)\end{array}$ & $\begin{array}{r}0.1202^{* *} \\
(9.71)\end{array}$ \\
\hline NASDAQ & $\begin{array}{r}0.0436^{* *} \\
(8.70)\end{array}$ & $\begin{array}{r}0.0427^{* *} \\
(8.53)\end{array}$ \\
\hline Stdev ret. & $\begin{array}{r}0.1494^{*} \\
(2.04)\end{array}$ & $\begin{array}{r}0.1550^{*} \\
(2.10)\end{array}$ \\
\hline
\end{tabular}

*significant at the $5 \%$ critical level, **significant at the $1 \%$ critical level 
Table 5:

Differences in Performance of Local and Distant Fund Portions (Annualized Returns)

The difference in average monthly returns between local and distant portions of a fund are reported below for various fund categories over the January, 1975 to December, 1994 time period. Every quarter each fund is split into a 'local' portion (defined as any holding located at least $95 \%$ closer to the fund than the average distance the fund is from all available securities) and a distant portion. Holdings within both the local and distant portions of funds are rescaled to sum to one. The average annualized return and Sharpe ratio (in brackets) to both of these portfolios are computed for each fund every month and then averaged across all funds (value-weighted by total asset value) and reported below, along with the average difference between the local and distant portions of funds ( $\mathrm{t}$-statistic in parentheses). Both raw excess returns (i.e., in excess of the three month Treasury Bill rate) and DGTW-adjusted returns (i.e., adjusted for size, book-to-market, and momentum) are reported. The table also reports the DGTW-return difference between local and distant portions of funds excluding investment in IPOs, and further adjusting the returns of each holding for regional effects. Finally, the last two columns of the table report the value-weighted DGTW-adjusted return of local stocks not being held by local funds (Sharpe ratio in brackets), and the difference between the performance of these firms and the local stocks actually being held by local funds (t-statistic in parentheses). We report statistics over the whole sample period, from 1975 to 1984, from 1985 to 1994, for each investment objective, for large, small, and remote city areas, and for the lowest and highest quintile of funds (Q1 and Q5, respectively) based on fund size (total asset value), number of holdings, age, number of IPOs held, fund turnover, and fund local bias.

\begin{tabular}{|c|c|c|c|c|c|c|c|c|c|c|}
\hline & \multicolumn{3}{|c|}{ Raw Excess Returns } & \multicolumn{7}{|c|}{ DGTW Adjusted Returns } \\
\hline & $\tilde{R}^{L}$ & $\tilde{R}^{D}$ & $\tilde{R}^{L}-\tilde{R}^{D}$ & $\tilde{R}^{L}$ & $\tilde{R}^{D}$ & $\tilde{R}^{L}-\tilde{R}^{D}$ & $\begin{array}{l}\text { Ex. IPOs } \\
\tilde{R}^{L}-\tilde{R}^{D}\end{array}$ & $\begin{array}{c}\text { Region } \\
\tilde{R}^{L}-\tilde{R}^{D}\end{array}$ & $\begin{array}{c}\text { Local } \\
\text { Not Held }\end{array}$ & $\tilde{R}^{L}-\tilde{R}^{L, N H}$ \\
\hline $1975-1994$ & $\begin{array}{c}0.0869 \\
{[0.42]}\end{array}$ & $\begin{array}{c}0.0615 \\
{[0.36]}\end{array}$ & $\begin{array}{c}0.0254 \\
(3.17)\end{array}$ & $\begin{array}{c}0.0191 \\
{[0.35]}\end{array}$ & $\begin{array}{l}0.0061 \\
{[0.21]}\end{array}$ & $\begin{array}{c}0.0130 \\
(3.93)\end{array}$ & $\begin{array}{c}0.0125 \\
(3.73)\end{array}$ & $\begin{array}{c}0.0119 \\
(3.62)\end{array}$ & $\begin{array}{c}-0.0082 \\
{[-0.20]}\end{array}$ & $\begin{array}{c}0.0273 \\
(6.90)\end{array}$ \\
\hline $1975-1984$ & $\begin{array}{c}0.1208 \\
{[0.46]}\end{array}$ & $\begin{array}{c}0.0682 \\
{[0.47]}\end{array}$ & $\begin{array}{l}0.0525 \\
(4.08)\end{array}$ & $\begin{array}{c}0.0228 \\
{[0.43]}\end{array}$ & $\begin{array}{c}-0.0009 \\
{[-0.05]}\end{array}$ & $\begin{array}{c}0.0238 \\
(5.12)\end{array}$ & $\begin{array}{l}0.0237 \\
(5.07)\end{array}$ & $\begin{array}{l}0.0229 \\
(4.87)\end{array}$ & $\begin{array}{c}-0.0130 \\
{[-0.25]}\end{array}$ & $\begin{array}{l}0.0358 \\
(4.79)\end{array}$ \\
\hline 1985-1994 & $\begin{array}{c}0.0547 \\
{[0.38]}\end{array}$ & $\begin{array}{c}0.0529 \\
{[0.24]}\end{array}$ & $\begin{array}{l}0.0017 \\
(0.19)\end{array}$ & $\begin{array}{c}0.0153 \\
{[0.27]}\end{array}$ & $\begin{array}{c}0.0130 \\
{[0.37]}\end{array}$ & $\begin{array}{l}0.0023 \\
(0.504)\end{array}$ & $\begin{array}{r}0.0012 \\
(0.27)\end{array}$ & $\begin{array}{l}0.0010 \\
(0.23)\end{array}$ & $\begin{array}{c}-0.0034 \\
{[-0.12]}\end{array}$ & $\begin{array}{l}0.0187 \\
(2.94)\end{array}$ \\
\hline \multicolumn{11}{|c|}{ Fund Objective } \\
\hline $\mathrm{AG}$ & $\begin{array}{c}0.0607 \\
{[0.27]}\end{array}$ & $\begin{array}{c}0.0989 \\
{[0.36]}\end{array}$ & $\begin{array}{c}-0.0382 \\
(-3.58)\end{array}$ & $\begin{array}{c}0.0213 \\
{[0.19]}\end{array}$ & $\begin{array}{c}0.0177 \\
{[0.31]}\end{array}$ & $\begin{array}{l}0.0035 \\
(0.52)\end{array}$ & $\begin{array}{l}0.0043 \\
(0.64)\end{array}$ & $\begin{array}{l}0.0038 \\
(0.57)\end{array}$ & $\begin{array}{c}-0.0084 \\
{[-0.15]}\end{array}$ & $\begin{array}{c}0.0297 \\
(3.66)\end{array}$ \\
\hline G & $\begin{array}{c}0.0991 \\
{[0.32]}\end{array}$ & $\begin{array}{l}0.0508 \\
{[0.38]}\end{array}$ & $\begin{array}{c}0.0484 \\
(4.67)\end{array}$ & $\begin{array}{c}0.0164 \\
{[0.22]}\end{array}$ & $\begin{array}{l}0.0072 \\
{[0.13]}\end{array}$ & $\begin{array}{l}0.0091 \\
(1.80)\end{array}$ & $\begin{array}{l}0.0094 \\
(1.84)\end{array}$ & $\begin{array}{l}0.0090 \\
(1.77)\end{array}$ & $\begin{array}{c}-0.0061 \\
{[-0.10]}\end{array}$ & $\begin{array}{c}0.0225 \\
(4.05)\end{array}$ \\
\hline G\&I & $\begin{array}{c}0.0886 \\
{[0.35]}\end{array}$ & $\begin{array}{c}0.0576 \\
{[0.36]}\end{array}$ & $\begin{array}{l}0.0311 \\
(3.53)\end{array}$ & $\begin{array}{c}0.0130 \\
{[0.24]}\end{array}$ & $\begin{array}{l}0.0033 \\
{[0.08]}\end{array}$ & $\begin{array}{l}0.0097 \\
(2.37)\end{array}$ & $\begin{array}{l}0.0083 \\
(2.03)\end{array}$ & $\begin{array}{l}0.0080 \\
(1.98)\end{array}$ & $\begin{array}{c}-0.0088 \\
{[-0.13]}\end{array}$ & $\begin{array}{c}0.0218 \\
(4.09)\end{array}$ \\
\hline Int. & $\begin{array}{c}0.0520 \\
{[0.26]}\end{array}$ & $\begin{array}{c}0.0993 \\
{[0.41]}\end{array}$ & $\begin{array}{c}-0.0474 \\
(-3.99)\end{array}$ & $\begin{array}{c}0.0089 \\
{[0.09]}\end{array}$ & $\begin{array}{c}0.0190 \\
{[0.30]}\end{array}$ & $\begin{array}{l}-0.0101 \\
(-1.39)\end{array}$ & $\begin{array}{c}-0.0132 \\
(-1.61)\end{array}$ & $\begin{array}{c}-0.0129 \\
(-1.58)\end{array}$ & $\begin{array}{l}0.0062 \\
{[0.14]}\end{array}$ & $\begin{array}{r}0.0027 \\
(0.39)\end{array}$ \\
\hline Bal. & $\begin{array}{c}0.0912 \\
{[0.35]}\end{array}$ & $\begin{array}{c}0.0690 \\
{[0.38]}\end{array}$ & $\begin{array}{l}0.0222 \\
(1.85)\end{array}$ & $\begin{array}{c}0.0189 \\
{[0.20]}\end{array}$ & $\begin{array}{c}0.0013 \\
{[0.02]}\end{array}$ & $\begin{array}{l}0.0176 \\
(2.41)\end{array}$ & $\begin{array}{l}0.0122 \\
(1.54)\end{array}$ & $\begin{array}{l}0.0114 \\
(1.45)\end{array}$ & $\begin{array}{c}-0.0124 \\
{[-0.12]}\end{array}$ & $\begin{array}{c}0.0313 \\
(4.01)\end{array}$ \\
\hline Other & $\begin{array}{c}0.0544 \\
{[0.30]}\end{array}$ & $\begin{array}{c}0.0526 \\
{[0.21]}\end{array}$ & $\begin{array}{c}0.0018 \\
(0.14)\end{array}$ & $\begin{array}{c}0.0191 \\
{[0.19]}\end{array}$ & $\begin{array}{c}-0.0127 \\
{[-0.20]}\end{array}$ & $\begin{array}{l}0.0318 \\
(4.44)\end{array}$ & $\begin{array}{c}0.0330 \\
(4.64)\end{array}$ & $\begin{array}{l}0.0317 \\
(4.50)\end{array}$ & $\begin{array}{c}-0.0079 \\
{[-0.09]}\end{array}$ & $\begin{array}{c}0.0270 \\
(3.34)\end{array}$ \\
\hline Metropol & an Are & & & & & & & & & \\
\hline Large & $\begin{array}{c}0.0763 \\
{[0.33]}\end{array}$ & $\begin{array}{c}0.0846 \\
{[0.40]}\end{array}$ & $\begin{array}{c}-0.0082 \\
(-1.55)\end{array}$ & $\begin{array}{c}0.0128 \\
{[0.22]}\end{array}$ & $\begin{array}{c}0.0018 \\
{[0.05]}\end{array}$ & $\begin{array}{c}0.0110 \\
(2.48)\end{array}$ & $\begin{array}{c}0.0103 \\
(2.32)\end{array}$ & $\begin{array}{c}0.0099 \\
(2.27)\end{array}$ & $\begin{array}{c}-0.0094 \\
{[-0.16]}\end{array}$ & $\begin{array}{c}0.0321 \\
(5.15)\end{array}$ \\
\hline Small & $\begin{array}{c}0.0920 \\
{[0.35]}\end{array}$ & $\begin{array}{c}0.0643 \\
{[0.45]}\end{array}$ & $\begin{array}{l}0.0277 \\
(2.87)\end{array}$ & $\begin{array}{c}0.0206 \\
{[0.34]}\end{array}$ & $\begin{array}{l}0.0076 \\
{[0.22]}\end{array}$ & $\begin{array}{l}0.0130 \\
(3.21)\end{array}$ & $\begin{array}{c}0.0123 \\
(3.04)\end{array}$ & $\begin{array}{l}0.0118 \\
(2.94)\end{array}$ & $\begin{array}{c}-0.0098 \\
{[-0.19]}\end{array}$ & $\begin{array}{c}0.0304 \\
(6.70)\end{array}$ \\
\hline Remote & $\begin{array}{c}0.1022 \\
{[0.39]}\end{array}$ & $\begin{array}{c}0.0655 \\
{[0.35]}\end{array}$ & $\begin{array}{l}0.0367 \\
(3.75)\end{array}$ & $\begin{array}{c}0.0227 \\
{[0.26]}\end{array}$ & $\begin{array}{c}0.0101 \\
{[0.23]}\end{array}$ & $\begin{array}{l}0.0126 \\
(2.31)\end{array}$ & $\begin{array}{l}0.0121 \\
(2.19)\end{array}$ & $\begin{array}{l}0.0115 \\
(2.09)\end{array}$ & $\begin{array}{c}-0.0085 \\
{[-0.13]}\end{array}$ & $\begin{array}{c}0.0332 \\
(5.74)\end{array}$ \\
\hline
\end{tabular}




\begin{tabular}{|c|c|c|c|c|c|c|c|c|c|c|}
\hline & \multicolumn{3}{|c|}{ Raw Excess Returns } & \multicolumn{7}{|c|}{ DGTW Adjusted Returns } \\
\hline & $\tilde{R}^{L}$ & $\tilde{R}^{D}$ & $\tilde{R}^{L}-\tilde{R}^{D}$ & $\tilde{R}^{L}$ & $\tilde{R}^{D}$ & $\tilde{R}^{L}-\tilde{R}^{D}$ & $\begin{array}{l}\text { Ex. IPOs } \\
\tilde{R}^{L}-\tilde{R}^{D}\end{array}$ & $\begin{array}{c}\text { Region } \\
\tilde{R}^{L}-\tilde{R}^{D}\end{array}$ & $\begin{array}{c}\text { Local } \\
\text { Not Held }\end{array}$ & $\tilde{R}^{L}-\tilde{R}^{L, N H}$ \\
\hline \multicolumn{11}{|c|}{ Fund Size (total asset value) } \\
\hline Q1 & 0.0855 & 0.0644 & 0.0211 & 0.0207 & 0.0052 & 0.0155 & 0.0155 & 0.0150 & -0.0089 & 0.0296 \\
\hline low & {$[0.35]$} & {$[0.43]$} & $(2.49)$ & {$[0.33]$} & {$[0.16]$} & $(3.89)$ & $(3.87)$ & $(3.76)$ & {$[-0.20]$} & $(6.43)$ \\
\hline Q5 & 0.0374 & 0.0886 & -0.0512 & 0.0037 & 0.0083 & -0.0046 & -0.0046 & -0.0047 & -0.0021 & 0.0058 \\
\hline high & {$[0.31]$} & {$[0.38]$} & $(-6.07)$ & {$[0.11]$} & {$[0.25]$} & $(-1.77)$ & $(-1.81)$ & $(-1.87)$ & {$[-0.05]$} & $(1.83)$ \\
\hline \multicolumn{11}{|c|}{ Number of Fund Holdings } \\
\hline Q1 & $\begin{array}{c}0.0848 \\
{[0.41]}\end{array}$ & $\begin{array}{c}0.0930 \\
{[0.36]}\end{array}$ & $\begin{array}{c}-0.0083 \\
(-0.94)\end{array}$ & $\begin{array}{c}0.0311 \\
{[0.34]}\end{array}$ & $\begin{array}{c}0.0090 \\
{[0.22]}\end{array}$ & $\begin{array}{c}0.0221 \\
(3.71)\end{array}$ & $\begin{array}{c}0.0229 \\
(3.81)\end{array}$ & $\begin{array}{c}0.0226 \\
(3.82)\end{array}$ & $\begin{array}{c}-0.0162 \\
{[-0.18]}\end{array}$ & $\begin{array}{c}0.0473 \\
(6.24)\end{array}$ \\
\hline Q5 & $\begin{array}{l}0.0265 \\
{[0.31]}\end{array}$ & $\begin{array}{c}0.0638 \\
{[0.28]}\end{array}$ & $\begin{array}{c}-0.0373 \\
(-2.91)\end{array}$ & $\begin{array}{c}0.0010 \\
{[0.02]}\end{array}$ & $\begin{array}{c}0.0014 \\
{[0.03]}\end{array}$ & $\begin{array}{c}-0.0005 \\
(-0.12)\end{array}$ & $\begin{array}{c}0.0005 \\
(0.12)\end{array}$ & $\begin{array}{c}0.0005 \\
(0.14)\end{array}$ & $\begin{array}{c}-0.0015 \\
{[-0.03]}\end{array}$ & $\begin{array}{c}0.0025 \\
(0.67)\end{array}$ \\
\hline \multicolumn{11}{|c|}{ Age of Fund } \\
\hline Q1 & $\begin{array}{c}0.0777 \\
{[0.31]}\end{array}$ & $\begin{array}{c}0.0566 \\
{[0.40]}\end{array}$ & $\begin{array}{c}0.0211 \\
(1.88)\end{array}$ & $\begin{array}{c}0.0160 \\
{[0.26]}\end{array}$ & $\begin{array}{c}0.0052 \\
{[0.13]}\end{array}$ & $\begin{array}{c}0.0107 \\
(2.38)\end{array}$ & $\begin{array}{c}0.0111 \\
(2.54)\end{array}$ & $\begin{array}{c}0.0108 \\
(2.48)\end{array}$ & $\begin{array}{c}-0.0093 \\
{[-0.15]}\end{array}$ & $\begin{array}{c}0.0252 \\
(5.24)\end{array}$ \\
\hline Q5 & $\begin{array}{c}0.0934 \\
{[0.38]}\end{array}$ & $\begin{array}{c}0.0698 \\
{[0.41]}\end{array}$ & $\begin{array}{r}0.0237 \\
(2.96)\end{array}$ & $\begin{array}{c}0.0224 \\
{[0.32]}\end{array}$ & $\begin{array}{c}0.0077 \\
{[0.25]}\end{array}$ & $\begin{array}{l}0.0147 \\
(3.48)\end{array}$ & $\begin{array}{l}0.0137 \\
(3.26)\end{array}$ & $\begin{array}{c}0.0130 \\
(3.12)\end{array}$ & $\begin{array}{c}-0.0050 \\
{[-0.11]}\end{array}$ & $\begin{array}{c}0.0274 \\
(5.40)\end{array}$ \\
\hline \multicolumn{11}{|c|}{ Number of IPOs Held by Funds } \\
\hline Q1 & $\begin{array}{c}0.0566 \\
{[0.43]}\end{array}$ & $\begin{array}{c}0.0791 \\
{[0.34]}\end{array}$ & $\begin{array}{c}-0.0225 \\
(-2.54)\end{array}$ & $\begin{array}{c}0.0223 \\
{[0.22]}\end{array}$ & $\begin{array}{c}0.0302 \\
{[0.33]}\end{array}$ & $\begin{array}{c}-0.0079 \\
(-0.98)\end{array}$ & $\begin{array}{c}-0.0110 \\
(-1.31)\end{array}$ & $\begin{array}{c}-0.0109 \\
(-1.31)\end{array}$ & $\begin{array}{c}0.0013 \\
{[0.02]}\end{array}$ & $\begin{array}{c}0.0210 \\
(2.93)\end{array}$ \\
\hline Q5 & $\begin{array}{c}0.1278 \\
{[0.39]}\end{array}$ & $\begin{array}{c}0.0819 \\
{[0.34]}\end{array}$ & $\begin{array}{c}0.0459 \\
(3.49)\end{array}$ & $\begin{array}{c}0.0151 \\
{[0.32]}\end{array}$ & $\begin{array}{c}0.0020 \\
{[0.07]}\end{array}$ & $\begin{array}{c}0.0131 \\
(4.58)\end{array}$ & $\begin{array}{l}0.0131 \\
(4.58)\end{array}$ & $\begin{array}{c}0.0123 \\
(4.36)\end{array}$ & $\begin{array}{c}-0.0092 \\
{[-0.21]}\end{array}$ & $\begin{array}{c}0.0243 \\
(5.54)\end{array}$ \\
\hline \multicolumn{11}{|c|}{ Fund Turnover } \\
\hline Q1 & $\begin{array}{c}0.0685 \\
{[0.35]}\end{array}$ & $\begin{array}{c}0.0448 \\
{[0.37]}\end{array}$ & $\begin{array}{c}0.0237 \\
(3.40)\end{array}$ & $\begin{array}{c}0.0071 \\
{[0.14]}\end{array}$ & $\begin{array}{c}-0.0022 \\
{[-0.07]}\end{array}$ & $\begin{array}{c}0.0092 \\
(2.90)\end{array}$ & $\begin{array}{c}0.0084 \\
(2.65)\end{array}$ & $\begin{array}{c}0.0080 \\
(2.57)\end{array}$ & $\begin{array}{c}-0.0025 \\
{[-0.06]}\end{array}$ & $\begin{array}{c}0.0096 \\
(2.36)\end{array}$ \\
\hline Q5 & $\begin{array}{c}0.1068 \\
{[0.38]}\end{array}$ & $\begin{array}{c}0.0654 \\
{[0.41]}\end{array}$ & $\begin{array}{c}0.0414 \\
(3.31)\end{array}$ & $\begin{array}{c}0.0241 \\
{[0.27]}\end{array}$ & $\begin{array}{c}0.0083 \\
{[0.15]}\end{array}$ & $\begin{array}{c}0.0158 \\
(2.52)\end{array}$ & $\begin{array}{c}0.0164 \\
(2.69)\end{array}$ & $\begin{array}{c}0.0163 \\
(2.64)\end{array}$ & $\begin{array}{c}-0.0143 \\
{[-0.16]}\end{array}$ & $\begin{array}{c}0.0384 \\
(4.69)\end{array}$ \\
\hline \multicolumn{11}{|c|}{ Fund Local Bias } \\
\hline Q1 & $\begin{array}{c}0.1070 \\
{[0.32]}\end{array}$ & $\begin{array}{c}0.1027 \\
{[0.35]}\end{array}$ & $\begin{array}{c}0.0044 \\
(0.39)\end{array}$ & $\begin{array}{c}0.0181 \\
{[0.12]}\end{array}$ & $\begin{array}{c}0.0096 \\
{[0.16]}\end{array}$ & $\begin{array}{c}0.0084 \\
(0.87)\end{array}$ & $\begin{array}{l}0.0125 \\
(1.27)\end{array}$ & $\begin{array}{l}0.0127 \\
(1.30)\end{array}$ & $\begin{array}{c}-0.0305 \\
{[-0.15]}\end{array}$ & $\begin{array}{c}0.0486 \\
(3.15)\end{array}$ \\
\hline Q5 & $\begin{array}{c}0.1106 \\
{[0.49]}\end{array}$ & $\begin{array}{c}0.0868 \\
{[0.35]}\end{array}$ & $\begin{array}{c}0.0238 \\
(2.80)\end{array}$ & $\begin{array}{l}0.0268 \\
{[0.26]}\end{array}$ & $\begin{array}{c}0.0061 \\
{[0.12]}\end{array}$ & $\begin{array}{c}0.0207 \\
(2.78)\end{array}$ & $\begin{array}{l}0.0187 \\
(2.45)\end{array}$ & $\begin{array}{c}0.0176 \\
(2.32)\end{array}$ & $\begin{array}{c}-0.0102 \\
{[-0.18]}\end{array}$ & $\begin{array}{c}0.0370 \\
(5.29)\end{array}$ \\
\hline
\end{tabular}


Table 6:

The Impact of Local Investment on the Cross-Section of Expected Returns

(Fama-MacBeth Cross-Sectional Individual Stock-Level Regressions)

Fama and MacBeth (1973) cross-sectional regressions are run every month on the universe of individual stocks held by at least one mutual fund in our sample ove the period January 1975 to December, 1994. Specifically, the cross-section of stock returns at time $t$ are regressed on a constant (not reported) and a host of firm characteristics: size (log of market capitalization at $t-1), \mathrm{BE} / \mathrm{ME}$, several individual and industry past return variables, the past year return of the region in which each stock is headquartered, and a remote city dummy (indicating whether the stock's headquarter's is outside of 250 kilometers of any of the 20 largest populated cities). The second regression adds a local ownership variable to these regressors. The local ownership measure, $L O$, is the difference between the average distance firm $j$ is from the mutual funds that actually hold it at time $t\left(d_{j}\right)$ and the distance firm $j$ is from all mutual funds $\left(d_{j}^{m}\right)$, scaled by the standard deviation of $d_{j}^{m}$ (e.g., $\left.L O_{j}=\frac{d_{j}^{m}-d_{j}}{\sigma_{j}^{m}}\right)$. The third regression replaces $L O$ with the percentage rank of $L O$, and the fourth regression replaces $L O$ with two dummy variables: the first dummy $\left(L D_{\text {low }}\right.$ ) assigns a one to firms in the bottom quintile of local ownership (and zero otherwise), and the second dummy ( $L D_{\text {mid }}$ ) assigns a one to firms in the middle three quintiles of local ownership. Time-series average coefficients and t-statistics (in parentheses) are reported below.

\section{Dependent Variable: Cross-Section of Stock Returns}

\begin{tabular}{|c|c|c|c|c|c|c|c|c|c|}
\hline size & $\mathrm{BE} / \mathrm{ME}$ & ret $_{-1:-1}$ & ret $_{-12:-2}$ & ret_-36:-13 & ind $-12:-1$ & $\operatorname{reg}_{-12:-1}$ & remote & & \\
\hline-0.0004 & 0.0019 & -0.0595 & 0.0081 & -0.0013 & 0.0130 & 0.0076 & -0.0007 & & \\
\hline$(-1.94)$ & $(2.13)$ & $(-10.57)$ & $(4.19)$ & $(-1.47)$ & $(2.35)$ & $(0.89)$ & $(-1.26)$ & & \\
\hline size & $\mathrm{BE} / \mathrm{ME}$ & ret $_{-1:-1}$ & ret $_{-12:-2}$ & ret_-36:-13 & $i n d_{-12:-1}$ & $\operatorname{reg}_{-12:-1}$ & remote & $L O$ & \\
\hline-0.0004 & 0.0019 & -0.0595 & 0.0080 & -0.0014 & 0.0129 & 0.0074 & -0.0003 & 0.0006 & \\
\hline$(-1.87)$ & $(2.15)$ & $(-10.54)$ & $(4.16)$ & $(-1.51)$ & $(2.32)$ & $(0.86)$ & $(-0.57)$ & $(2.24)$ & \\
\hline size & $\mathrm{BE} / \mathrm{ME}$ & ret $_{1: 1}$ & ret $_{2: 12}$ & ret $_{13: 36}$ & ind $_{1: 12}$ & $\operatorname{reg}_{1: 12}$ & remote & \%rank & \\
\hline-0.0003 & 0.0019 & -0.0598 & 0.0081 & -0.0014 & 0.0131 & 0.0084 & -0.0002 & 0.0030 & \\
\hline$(-1.65)$ & $(2.07)$ & $(-10.65)$ & $(4.18)$ & $(-1.49)$ & $(2.37)$ & $(0.98)$ & $(-0.28)$ & $(2.68)$ & \\
\hline size & $\mathrm{BE} / \mathrm{ME}$ & ret $_{1: 1}$ & ret $_{2: 12}$ & ret $_{13: 36}$ & ind $_{1: 12}$ & $\operatorname{reg}_{1: 12}$ & remote & $L D_{\text {low }}$ & $L D_{\text {mid }}$ \\
\hline-0.0004 & 0.0020 & -0.0596 & 0.0080 & -0.0014 & 0.0127 & 0.0075 & -0.0003 & -0.0017 & -0.0012 \\
\hline$(-1.88)$ & $(2.15)$ & $(-10.56)$ & $(4.17)$ & $(-1.54)$ & $(2.29)$ & $(0.86)$ & $(-0.58)$ & $(-1.91)$ & $(-2.13)$ \\
\hline
\end{tabular}


Table 7:

Locally Owned Sorted Portfolios

(Monthly Returns)

Average monthly returns on portfolios sorted by local ownership are reported over the January, 1975 to December, 1994 time period. Every month we sort stocks into quintiles based on $L O$ from the previous quarter, which is the difference between the average distance firm $j$ is from the mutual funds that actually hold it $\left(d_{j}\right)$ and the distance firm $j$ is from all mutual funds $\left(d_{j}^{m}\right)$, scaled by the standard deviation of $d_{j}^{m}$ (e.g., $L O_{j}=\frac{d_{j}^{m}-d_{j}}{\sigma_{j}^{m}}$ ). The value-weighted average return of the quintile portfolios are computed every month and time-series averages and t-statistics (in parentheses) are reported for the highest and lowest $L O$ quintile portfolios ( $L O 5$ and $L O 1$, respectively), as well as the difference between them $(L O 5-1)$. We also report the DGTW-adjusted value-weighted returns of the highest minus lowest $L O$ quintile portfolio $(L O 5-1)$ and report the Jensen's $\alpha$ from a regression of this portfolio return on the Carhart (1997) four factor model. In addition, we perform double sorts on size (market capitalization), fraction of outstanding shares held by mutual funds, and BE/ME, where we first sort stocks into size tretiles, and then sort stocks within each tretile into quintiles based on $L O$. We repeat this procedure for fraction of equity held by mutual funds (defined for firm $j$ as the number of shares of stock $j$ held by all mutual funds divided by the number of shares outstanding of firm $j$ ), as well as BE/ME.

\begin{tabular}{|c|c|c|c|c|c|}
\hline & \multicolumn{3}{|c|}{ Raw Returns } & \multirow{2}{*}{$\begin{array}{c}\text { DGTW Returns } \\
L O 5-1\end{array}$} & \multirow{2}{*}{$\begin{array}{c}\text { 4-factor } \alpha \\
L O 5-1\end{array}$} \\
\hline & $L O 1$ & $L O 5$ & $L O 5-1$ & & \\
\hline Unconditional & $\begin{array}{l}0.0121 \\
(3.68)\end{array}$ & $\begin{array}{l}0.0145 \\
(4.28)\end{array}$ & $\begin{array}{l}0.0026 \\
(1.92)\end{array}$ & $\begin{array}{l}0.0019 \\
(1.31)\end{array}$ & $\begin{array}{c}0.0021 \\
(1.29)\end{array}$ \\
\hline \multicolumn{6}{|l|}{ Size } \\
\hline small & $\begin{array}{c}0.0178 \\
(4.13)\end{array}$ & $\begin{array}{c}0.0223 \\
(4.62)\end{array}$ & $\begin{array}{l}0.0045 \\
(2.79)\end{array}$ & $\begin{array}{c}0.0028 \\
(2.14)\end{array}$ & $\begin{array}{l}0.0031 \\
(2.11)\end{array}$ \\
\hline medium & $\begin{array}{c}0.0142 \\
(3.66)\end{array}$ & $\begin{array}{l}0.0171 \\
(4.33)\end{array}$ & $\begin{array}{l}0.0028 \\
(1.61)\end{array}$ & $\begin{array}{l}0.0017 \\
(1.31)\end{array}$ & $\begin{array}{l}0.0020 \\
(1.45)\end{array}$ \\
\hline large & $\begin{array}{l}0.0111 \\
(3.75)\end{array}$ & $\begin{array}{c}0.0112 \\
(3.80)\end{array}$ & $\begin{array}{l}0.0001 \\
(0.09)\end{array}$ & $\begin{array}{l}-0.0006 \\
(-0.50)\end{array}$ & $\begin{array}{l}0.0011 \\
(0.72)\end{array}$ \\
\hline \multicolumn{6}{|c|}{ Fraction of Equity Held by Mutual Funds } \\
\hline low & $\begin{array}{c}0.0116 \\
(3.63)\end{array}$ & $\begin{array}{l}0.0114 \\
(3.88)\end{array}$ & $\begin{array}{c}-0.0002 \\
(-0.10)\end{array}$ & $\begin{array}{c}0.0013 \\
(0.60)\end{array}$ & $\begin{array}{l}0.0013 \\
(0.50)\end{array}$ \\
\hline middle & $\begin{array}{c}0.0129 \\
(3.68)\end{array}$ & $\begin{array}{c}0.0134 \\
(3.91)\end{array}$ & $\begin{array}{l}0.0005 \\
(0.25)\end{array}$ & $\begin{array}{l}0.0007 \\
(0.43)\end{array}$ & $\begin{array}{c}0.0012 \\
(0.53)\end{array}$ \\
\hline high & $\begin{array}{c}0.0136 \\
(3.28)\end{array}$ & $\begin{array}{c}0.0176 \\
(4.38)\end{array}$ & $\begin{array}{c}0.0040 \\
(2.56)\end{array}$ & $\begin{array}{c}0.0031 \\
(2.29)\end{array}$ & $\begin{array}{l}0.0051 \\
(2.82)\end{array}$ \\
\hline \multicolumn{6}{|l|}{$\mathrm{BE} / \mathrm{ME}$} \\
\hline low & $\begin{array}{l}0.0094 \\
(2.58)\end{array}$ & $\begin{array}{c}0.0120 \\
(3.00)\end{array}$ & $\begin{array}{l}0.0026 \\
(2.10)\end{array}$ & $\begin{array}{l}-0.0003 \\
(-0.55)\end{array}$ & $\begin{array}{l}0.0004 \\
(0.17)\end{array}$ \\
\hline middle & $\begin{array}{l}0.0125 \\
(3.65)\end{array}$ & $\begin{array}{c}0.0123 \\
(3.62)\end{array}$ & $\begin{array}{c}-0.0002 \\
(-0.07)\end{array}$ & $\begin{array}{l}-0.0007 \\
(-0.36)\end{array}$ & $\begin{array}{l}0.0008 \\
(0.35)\end{array}$ \\
\hline high & $\begin{array}{l}0.0143 \\
(4.69)\end{array}$ & $\begin{array}{l}0.0148 \\
(4.52)\end{array}$ & $\begin{array}{c}0.0004 \\
(0.22)\end{array}$ & $\begin{array}{c}0.0013 \\
(0.71)\end{array}$ & $\begin{array}{c}0.0003 \\
(0.16)\end{array}$ \\
\hline
\end{tabular}


Table 8:

Abnormal Turnover Across Fund and Stock Attributes

(Fama-MacBeth Cross-Sectional Holdings-Level Regressions)

Cross-sectional regressions of the abnormal turnover of a holding on a host of fund and stock attributes are conducted over the period January, 1975 to December, 1994. The dependent variable is the abnormal turnover of each holding. For fund $i$ holding firm $j$, this is defined as the number of shares bought or sold in firm $j$ divided by the number of shares held in the previous quarter by fund $i$ in firm $j$, minus the expected value of turnover in firm $j$. The expected value of turnover in firm $j$ is approximated by the average daily trading volume in firm $j$ over the last year. The cross-section of abnormal turnover measures are regressed on a constant (not reported), the same fund and stock attributes from Table 4 plus the percent local bias measure from equation (4). The coefficients from these regressions are average over time in the style of Fama and MacBeth (1973) and reported below along with their time-series t-statistics (in parentheses).

\begin{tabular}{|c|c|c|c|}
\hline $\ln$ (assets) & $\begin{array}{c}-1247^{* *} \\
(-3.96)\end{array}$ & & $\begin{array}{c}-0.1153^{* *} \\
(-3.88)\end{array}$ \\
\hline \# holdings & $\begin{array}{c}0.0003^{* *} \\
(3.97)\end{array}$ & & $\begin{array}{c}0.0001^{* *} \\
(3.82)\end{array}$ \\
\hline age & $\begin{array}{c}0.0080^{* *} \\
(2.54)\end{array}$ & & $\begin{array}{c}0.0077^{*} \\
(2.43)\end{array}$ \\
\hline small city & $\begin{array}{c}0.0154^{*} \\
(2.16)\end{array}$ & & $\begin{array}{c}0.0146^{*} \\
(2.11)\end{array}$ \\
\hline remote city & $\begin{array}{c}0.0901^{* *} \\
(6.74)\end{array}$ & & $\begin{array}{c}0.0892^{* *} \\
(6.39)\end{array}$ \\
\hline $\ln ($ size $)$ & & $\begin{array}{c}-0.2694^{*} \\
(-2.27)\end{array}$ & $\begin{array}{c}-0.2744^{*} \\
(-2.30)\end{array}$ \\
\hline $\mathrm{BE} / \mathrm{ME}$ & & $\begin{array}{c}0.0687^{* *} \\
(8.31)\end{array}$ & $\begin{array}{c}0.0681^{* *} \\
(8.26)\end{array}$ \\
\hline ret $_{-1:-1}$ & & $\begin{array}{l}0.0227 \\
(0.73)\end{array}$ & $\begin{array}{c}0.0235 \\
(0.68)\end{array}$ \\
\hline ret $_{-12:-2}$ & & $\begin{array}{l}-0.1887 \\
(-1.32)\end{array}$ & $\begin{array}{l}-0.1920 \\
(-1.22)\end{array}$ \\
\hline ret $_{-36:-13}$ & & $\begin{array}{c}-0.0662 \\
(-1.54)\end{array}$ & $\begin{array}{c}-0.0653 \\
(-1.35)\end{array}$ \\
\hline ind $_{-12:-1}$ & & $\begin{array}{c}2.3891^{* *} \\
(5.36)\end{array}$ & $\begin{array}{c}2.7290^{* *} \\
(5.77)\end{array}$ \\
\hline$r e g_{-12:-1}$ & & $\begin{array}{c}-0.3781^{* *} \\
(-2.51)\end{array}$ & $\begin{array}{c}-0.3624^{*} \\
(-2.49)\end{array}$ \\
\hline$D_{i p o}$ & & $\begin{array}{c}-0.2396 \\
(-0.61)\end{array}$ & $\begin{array}{c}-0.2531 \\
(-0.79)\end{array}$ \\
\hline NASDAQ & & $\begin{array}{c}-0.1860^{*} \\
(-1.97)\end{array}$ & $\begin{array}{c}-0.1848 \\
(-1.92)\end{array}$ \\
\hline Stdev ret. & & $\begin{array}{c}-0.4502^{* *} \\
(-11.41)\end{array}$ & $\begin{array}{c}-0.4480^{* *} \\
(-11.36)\end{array}$ \\
\hline $\mathrm{LB} \%$ & $\begin{array}{c}-2.9437^{* *} \\
(-9.67)\end{array}$ & $\begin{array}{c}-2.1881^{* *} \\
(-9.47)\end{array}$ & $\begin{array}{c}-2.1190^{* *} \\
(-9.53)\end{array}$ \\
\hline
\end{tabular}

*significant at the $5 \%$ critical level, **significant at the $1 \%$ critical level 
Table 9:

The Impact of Local Investment on Mutual Fund Herding (Fama-MacBeth Cross-Sectional Individual Stock-Level Regressions)

Fama and MacBeth (1973) cross-sectional regressions are run every month on the universe of individual stocks held by at least one of our sample of mutual funds over the period January, 1975 to December, 1994. Specifically, the cross-section of stock herding measures at time $t$ are regressed on a constant (not reported) and a host of firm characteristics: size (log of market capitalization at $t-1), \mathrm{BE} / \mathrm{ME}$, several individual and industry past return variables, the past year return of the region in which each stock is headquartered, a remote city dummy (indicating whether the stock's headquarter's is outside of 250 kilometers of any of the 20 largest populated cities), and the local ownership variable $L O$. The dependent variable is the cross-section of herding measures, $H M_{j, t}$, defined as the absolute value of the proportion of all funds trading stock $j$ that are buyers minus the proportion of total buys to total trades in all stocks across all funds at time $t$. The time-series average of the regression coefficients are reported below, along with their time-series t-statistics (in parentheses).

\section{Dependent Variable: Cross-Section of Stock Herding Measures}

\begin{tabular}{|cccccccc|}
\hline size & BE/ME & ret $_{-1:-1}$ & ret $_{-12:-2}$ & ret $_{-36:-13}$ & ind $_{-12:-1}$ & reg \\
\hline-0.0089 & -0.0036 & -0.0216 & -0.0016 & 0.0004 & 0.0089 & 0.0063 & remote \\
$(-12.46)$ & $(-3.03)$ & $(-2.47)$ & $(-0.61)$ & $(0.39)$ & $(1.02)$ & $(0.40)$ & $(-1.67)$
\end{tabular}

\begin{tabular}{|ccccccccc|}
\hline size & BE/ME & ret $_{-1:-1}$ & ret $_{-12:-2}$ & ret $_{-36:-13}$ & ind & & & \\
$-12:-1$ & reg & $-12:-1$ & remote & $L O \%$ \\
\hline-0.0086 & -0.0041 & -0.0212 & -0.0020 & 0.0005 & 0.0097 & 0.0057 & -0.0020 & -0.0079 \\
$(-12.14)$ & $(-3.34)$ & $(-2.35)$ & $(-0.69)$ & $(0.48)$ & $(1.11)$ & $(0.23)$ & $(-1.81)$ & $(-9.36)$ \\
& & & & & & & \\
\hline \hline
\end{tabular}

